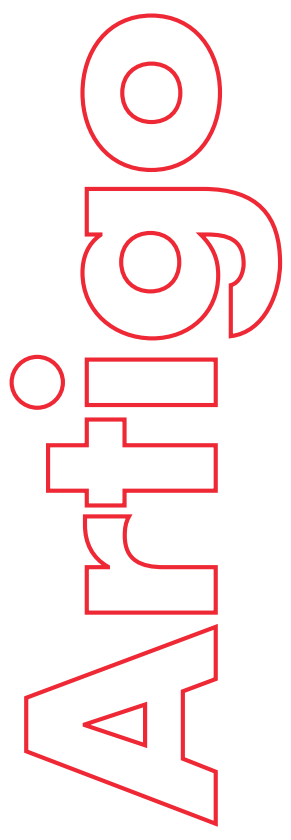

\title{
A GEOGRAFIA, ANTES DE MAIS NADA SERVE PARA MEDIAR A PAZ PELA INFRAESTRUTURA DE DADOS ESPACIAIS DA GEOPOLITICA AO GEODIREITO
}

\section{Luiz Ugeda}

p. $01-51$

\section{Revista}

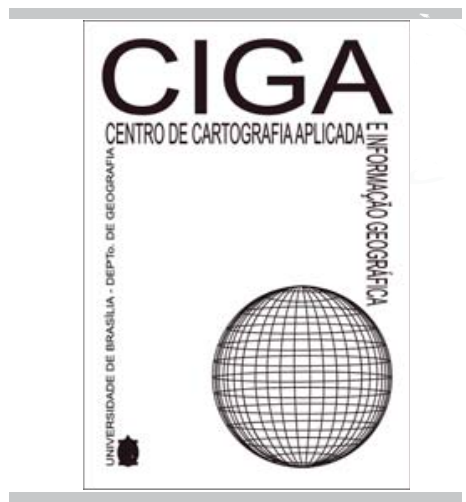

Revista Eletrônica: Tempo - Técnica Território, V.10, N.1 (2019), 01:51 ISSN : 2177-4366

DOI: https://doi.org/10.26512/ ciga.v10i1.27217
Como citar este ar tigo:

Ugeda, L. A GEOGRAFIA, ANTES DE MAIS NADA, SERVE PARA MEDIAR A PAZ PELA INFRAESTRUTURA DE DADOS ESPACIAIS DA GEOPOLÍTICA AO GEODIREITO. Revista Eletrônica: Tempo - Técnica - Território, v.10, n.1 (2019), p. 01:51 ISSN: 2177-4366. DOI: https://doi.org/10.26512/ ciga.v10i1.27217

\section{Disponível em:}

http://periodicos.unb.br/index.php/ciga/

Este obra está licenciado com uma Licença Creative Commons Atribuição-NãoComercial 4.0 Internacional. 


\section{A GEOGRAFIA, ANTES DE MAIS NADA, SERVE PARA \\ MEDIAR A PAZ PELA INFRAESTRUTURA DE DADOS ESPACIAIS \\ DA GEOPOLÍTICA AO GEODIREITO}

Luiz Ugeda ${ }^{1}$

RESUMO: O uso de fatos, valores e técnicas geográficas foram implementadas, em menor ou maior grau, por todas as civilizações ao longo da história. No século XXI, a conversão destas dimensões geográficas enquanto políticas públicas têm possibilitado que a Geografia, por meio da interdisciplinaridade com o Direito, seja cada vez mais importante para a mediação de interesses espaciais

Palavras-chave: Geodireito; Dados Espaciais; Justiça territorial; Ordenamento territorial, interesses espaciais

ABSTRACT: The use of facts, values and geographical techniques has been implemented to a lesser or greater extent by all civilizations throughout history. In the 21 st century, the conversion of these geographical dimensions and the public policies that allow geography, through interdisciplinarity or law, are increasingly important for the mediation of spatial interests.

Keywords: Geodright; Spatial data; Territorial justice; Spatial planning, spatial interests

\section{Introdução}

Lacoste $^{2}$ se notabilizou na Geografia, dentre outros ensinamentos, ao dizer que ela serve, antes de mais nada, para fazer a guerra. Esta frase, de tão poderosa, encantou gerações de geógrafos e serviu, dentre outras coisas, para atribuir um caráter didático as explicações acadêmicas. Afinal, a Geografia é o fundamento de algo tão fascinante, grandioso, épico e controverso quanto uma guerra. Mas atrás das obviedades desta frase, amplamente repetida em diversos rincões mundo afora, existe um emprego muito mais profundo e silencioso a Geografia.

\footnotetext{
${ }^{1}$ Doutor em Geografia (Universidade de Brasília), doutorando em Direito (Universidade de Coimbra), sendo Mestre em Direito e em Geografia (Pontifícia Universidade Católica de São Paulo). las@ geodireito.com

${ }^{2}$ Yves LACOSTE, La géographie, ça sert, d'abord, à faire la guerre. Paris, Maspero. Petite coll. Maspero n. 165, 1976.
}

Revista Eletrônica: Tempo - Técnica - Território, V.10, N.1 (2019), 01:51 ISSN: 2177-4366 
A Geografia serve a guerra por ser um poderoso instrumento de organização, sem a qual nenhuma contenda subsiste. Uma organização que se presta a um governo que controla para se apropriar, com suas forças, de determinado espaço. Este alguém, que pode ser um Estado, deve necessariamente ocupar um lugar nesse espaço, por meio de seu território. E a Geografia desenvolvida no interior desse Estado, mais que servir para organizar uma guerra, se presta a orientar o espaço de um país.

O enlaçamento secular entre a Geografia e a Ciência Política encontra uma outra interdisciplinaridade tão poderosa quanto a constituição da Geopolítica. É a sua contraparte em tempos de paz. Se fizermos uma análise etimológica da expressão "ordenamento territorial", talvez possamos encontrar a mais poderosa síntese de articulação entre a Geografia e o Direito. Direito é ordem, Geografia é território. Direito é "como", Geografia é "onde". O Direito delimita obrigações e garantias com base em uma localização fornecida pela Geografia. O Direito analisa a normatização do legislador e a Geografia estuda os mapeamentos dos cartógrafos e os dados dos estatísticos. E é nessa dimensão instrumental que o diálogo floresce e se consolida como algo mais do que possível e factível, mas como necessário para viabilizar a vida coletiva, a relação das sociedades perante seus espaços de influência.

A articulação entre Geografia e Direito nasce pela aplicação do princípio da simetria, ${ }^{3}$ que confere uma configuração técnica ${ }^{4}$ a esse diálogo. Afinal, conforme ensina Ortega y Gasset, ${ }^{5}$ o primeiro filósofo profissional a discorrer sobre a técnica, ${ }^{6}$ sem o instrumentalismo o homem não existiria e nem teria existido. Assim, sem mais nem menos. Esta técnica miscigenada, ou geojurídica, consiste na elaboração de uma relação cognitiva instrumental (técnica-técnica) entre Geografia e Direito como uma ferramenta interdisciplinar.

É a convergência do sistema mapa (representações de territórios, lugares, regiões, paisagens, escalas) e do sistema norma (representações de suas fontes, jurisprudências,

\footnotetext{
${ }^{3}$ David BLOOR (Knowledge and Social Imagery, Chicago: The University of Chicago Press, 1991, pp. 35), propôs o princípio da simetria entre o verdadeiro e o falso, sendo que ambos necessitam ser explicados da mesma forma, no esforço de se definir o conhecimento enquanto crença compartilhada e, por conseguinte, passível de análise pela sociologia. Trata-se de realizar uma abordagem fenomenológica à ciência, ao propor uma visão bipartida do universo, entre o conhecido e o conhecível, em duas classes que abarcam tudo o que existe, mas que se excluem mutuamente de modo radical. O desafio e o pressuposto de se estudar temas que a primeira vista parecem antagônicos são análogos ao que levou Bruno LATOUR (Nous n'avons jamais été modernes, Essai d'anthropologie symétrique. Paris, La Dé-couverte, 1991, 30) a elaborar sua Antropologia Simétrica, com base na simetria entre a sociedade e a natureza.

${ }^{4}$ Para Martin HEIDEGGER (<<A questão da técnica $\gg$ >. In: Ensaios e Conferências. Petrópolis: Vozes, 2002, 26), a técnica moderna precisa utilizar as ciências exatas da natureza porque sua essência repousa na composição.

${ }^{5}$ José ORTEGA Y GASSET, Meditación de la técnica y otros ensayos sobre ciência y filosofia. Madrid: Alianza, 1998 pp. 1.

${ }^{6}$ Carl MITCHAM, ¿Qué es la filosofía de la tecnología?. Barcelona: Anthropos Editorial del Hombre. 1990 pp. 58).
}

Revista Eletrônica: Tempo - Técnica - Território, V.10, N.1 (2019), 01:51 ISSN: 2177-4366 
competências, analogias, usos e costumes). É o mapa com força cogente e a norma com critério espacial. É um renovado sistema de referência, que não substitui a realidade, mas a sistematiza e nela interfere. E esse conjunto de signos - mapas e normas - encontra uma função central no planejamento. Afinal, a Geografia se transforma em um recurso do Direito na obtenção de liberdade, de ordem e de justiça, ao passo que o Direito se incorpora enquanto ferramenta da Geografia na consecução de solidariedade enquanto coesão espacial pela coercitividade.

O mapa instrumentaliza o espaço da sociedade, por meio da Geografia, ao passo que a norma ordena mecanismos de coerção por intermédio do Direito. Assim, as políticas públicas espaciais consolidam o instrumentalismo jurídico e geográfico, cristalizando um enorme paradigma para o desenvolvimento do ordenamento territorial. Se as coisas circulam, e os cidadãos têm o direito de ir e vir, cabe a eles saberem para "onde". Em uma perspectiva historiográfica, resta analisar qual foi o percurso científico que trouxe a humanidade até esse ponto, quais são os métodos empregados atualmente e qual é o protagonismo que o Estado deve ter para corresponder aos desafios contemporâneos.

\section{DA GEOPOLÍTICA AO GEODIREITO: UMA CONTEXTUALIZAÇÃo HISTÓRICA}

A história nos mostra que o enlaçamento entre Geografia e Direito é milenar, algumas vezes contraditório, mas sempre expressando uma relação clara de poder. É uma interação simbiótica entre meios e fins. O Direito usa a Geografia, seus dados, informações, análises, diagnósticos e planejamento para estabelecer uma ordem interna como seu fim. Já a Geografia usa o Direito como meio, junto a sua capacidade coercitiva, para viabilizar sua finalidade: localizar coisas no território.

Se em uma visão geopolítica cabe a Geografia fazer a guerra, sob a ótica geojurídica ela passa a ser elemento indissociável de mediação da paz, em prol do ordenamento territorial. Há a premência de se conferir aos cidadãos uma noção clara de pertencimento e de hierarquia, por meio da soberania e de uma representação no espaço. Nesse contexto, é conveniente voltar e dar uma grande olhada na profunda alameda do passado, ${ }^{7}$ pois nela aprendemos como a Geografia foi usada como política pública.

\section{A Era dos Censos (até 1494)}

\footnotetext{
${ }^{7}$ José ORTEGA Y GASSET, Tierras de Castilla, El espectador. Madrid: Alianza, p. 177-192, 1998 pp. 44.

Revista Eletrônica: Tempo - Técnica - Território, V.10, N.1 (2019), 01:51 ISSN: 2177-4366
} 
É recorrente na história da humanidade a necessidade de gerir recursos perante o território de forma quantitativa e qualitativa. Isso significa dominar técnicas para classificar a produção alimentar, ordenar a mão-de-obra, identificar rotas de deslocamento, criar mecanismos de acumulação de bens e recursos naturais, dentre outros. Para tanto, a realização de contagem aritmética sempre foi uma tônica que permeou esse tipo de conduta. A técnica geográfica é o grande ponto de inflexão que transforma políticas públicas espaciais em geográficas, pois é a Geografia, enquanto ciência, que orientará estas práticas de poder.

O primeiro registro do emprego da Geografia enquanto política pública foi realizado pela Babilônia em 3.800 a.C., há cerca de 6.000 anos. ${ }^{8}$ Registros sugerem que a contagem da população foi realizada em seis ou sete anos, tendo cadastrado o número de pessoas, animais, quantidade de manteiga, mel, leite, lã e legumes. Em 2.500 a.C., o Egito efetuou um censo para avaliar a força de trabalho disponível para a construção de pirâmides, sendo que em aproximadamente 1490 a.C., Israel teria realizado uma contagem de pessoas responsáveis por impostos e serviço militar.

Nesse contexto existente na Antiguidade, duas civilizações se destacaram no implemento dessa técnica. Na China, Confúcio compilou obra, em torno de 500 a.C., que tratava não apenas a contagem da população chinesa, mas também continha dados agrícola, industrial, comercial e outras estatísticas ${ }^{9}$ que remonta ao tempo do Imperador Yao. ${ }^{10}$ Os romanos, por sua vez, sistematizaram a técnica e acabaram por batizá-la como "census", ou censo, enquanto conjunto de dados estatísticos destinados a identificar e cadastrar dados em função do território, podendo ser uma cidade, região ou província. ${ }^{11}$ Se os chineses conseguiram convergir o desenvolvimento dos censos ao avanço tecnológico da bússola, os romanos deram uma importante contribuição no sentido de criar o voto censitário, base para o reconhecimento de um direito político. Afinal, somente teria direitos, seria cidadão, a pessoa que estivesse inscrita no censo. A contraparte dos

\footnotetext{
${ }^{8}$ GREAT BRITAIN PARLIAMENT, Counting the Population, Volume 1. House of Commons. Treasury Committee The Stationery Office, 2008, pp. 9 e ss.

${ }^{9}$ Pierre LAFFITTE, A general view of Chinese civilization and of the relations of the West with China. London, Teubnee \& Co., Ludgate Hill, 1887, pp. 38.

${ }^{10} \mathrm{O}$ Imperador Yao reinou por volta de 2.238 a.C. Mesmo com informações incompletas, é possível identificar importantes eventos públicos e demonstrar a importância histórica do emprego da estatística enquanto elemento central do exercício de poder. No século I a.C., os chineses descobririam que o emprego da magnetite possibilitaria encontrar os pontos cardeais, inventando a bússola, que teria enorme emprego na orientação espacial nos séculos e milênios seguintes.

11 Segundo Claude NICOLET, (Contrôle de l'espace humain : les recensements. L'inventaire du monde: géographie et politique aux origines de l'Empire romain. Paris: Fayard, 1988, pp. 78), seus conhecimentos derivaram dos censos gregos realizados desde o século VIII a.C. e, em que pese as dificuldades de interpretação e levantamento de dados históricos, pode-se afirmar que os romanos fizeram ao menos 37 censos entre 508 e 28 a.C. Dionísio de ALICARNASSO (Antichità Romane, Livro IX, domínio público, 27) chegou a aferir uma população em Roma de 5 milhões de pessoas no momento do nascimento de Cristo.
}

Revista Eletrônica: Tempo - Técnica - Território, V.10, N.1 (2019), 01:51 ISSN: 2177-4366 
direitos decorrentes do censo eram suas obrigações fiscais, que se intensificariam nos séculos seguintes.

Pode-se perceber que o censo na Europa da Idade Média tinha uma importância central para definir as obrigações feudais dos servos. Muitas vezes era caracterizado como tributo, onde os vilões (oriundos das vilas) deveriam pagar a nobreza. Por exemplo, no Império Carolíngio do século VIII, de Carlos Magno, as famílias praticavam uma economia de subsistência e pagavam ao senhor o censo pelo usufruto da terra. O Rei Guilherme I, da Inglaterra, promoveu o Domesday Book em 1085, criando um grande compêndio de todas as propriedades rurais. As taxas eram listadas por jurisdição, na qual os súditos estavam situados, não necessariamente por localização geográfica, tendo sido um mecanismo extremamente impopular. ${ }^{12}$

Imagem 1

Página do Domesday Book

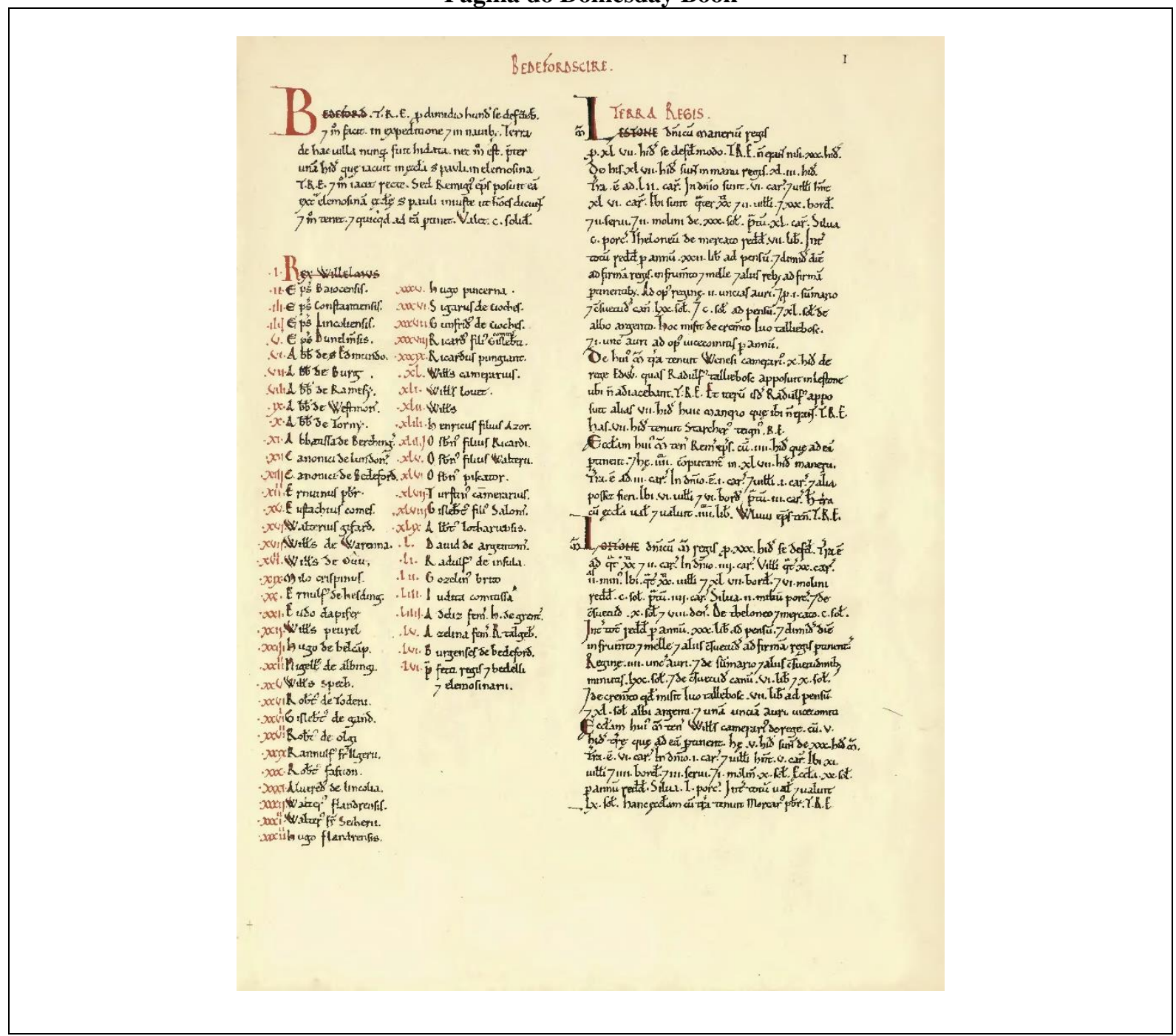

${ }^{12}$ Alan PALMER, Kings and Queens of England. Great Britain: Octopus Books Limited, 1976 pp. 15. 
Fonte: Arquivo Nacional do Reino Unido ${ }^{13}$

Concomitantemente, na Península Ibérica sob domínio muçulmano, eram elaborados censos e cadastros de maneira a possibilitar cobrança tributária, ${ }^{14}$ e exercer a ordem do dar-alIslam. ${ }^{15}$ Como exemplo, a Independência de Portugal, por força do Tratado de Zamora de 1143, impunha um pagamento de censo anual a Santa Sé, ${ }^{16}$ sem o qual o reino não seria registrado e reconhecido perante Deus e, por conseguinte, não existiria.

Desde então os censos estão na base da formação territorial de todos os estados ocidentais, ${ }^{17}$ sendo sua prática uma etapa imprescindível para reconhecimento de direitos e cobrança de tributos. A Rússia realizou censos em 1245, 1259, 1273 e $1287 .{ }^{18}$ Na França de 1328, o censo se transformaria em uma espécie de base do direito público na Idade Média. O censo era uma técnica fundamental na produção de segurança jurídica e social, sem o qual o État des Subsides não se viabilizaria. O censo, enquanto técnica estatística e fiscal, teve um papel central na Guerra dos Cem Anos (1337 a 1453) na gestão de recursos escassos, fossem militares, fossem financeiros.

Essa técnica se disseminava em diversas outras regiões europeias, como foi o caso da República de Veneza, que realizou seu primeiro censo incluindo todo seu território em 1338. Mas também era uma prática identificada em outras regiões do mundo. Na América précolombiana, os incas mantinham, por meio de cordas, o sistema de quipu, que operava um sofisticado método de cálculo e de organização social com o objetivo de ordenar o território. ${ }^{19}$ Na Europa, surgiam os primeiros mapeamentos destinados a mostrar as melhores rotas para comerciantes, como o Mapa-mundi genovês, de 1457, que se destinava basicamente a identificar as melhores rotas para as Índias.

\footnotetext{
${ }^{13}$ Vide em <http://www.nationalarchives.gov.uk/domesday/discover-domesday/great-domesday.htm>

${ }^{14}$ Bernard F. REILLY, <<A evolução da sociedade Ibérica (1031-1072)〉>. In: Cristãos e Muçulmanos:

A luta pela Península Ibérica. Editora Teorema, 1992, pp. 35.

${ }^{15}$ Em tradução livre, "a terra do islão".

${ }^{16}$ José MATTOSO, D. Afonso Henriques. $2^{\mathrm{a}}$ Ed. Lisboa: Temas e Debates, 2014 pp. 213.

${ }^{17}$ Os primeiros censos portugueses datam do Rol dos Besteiros do conto de D. Afonso III (1260-1279) e de D. João I (1421-1422), restringindo-se a apurar homens aptos para a guerra.

18 Boris Vladimirovich GNEDENKO (Б. В. ГНЕДЕНКО), Курс теории вероятностей. Москва: Государственное издательство технико-математической литературы, 1950 pp. 355.

${ }^{19}$ Suzan NILES, Considering Quipus: Andean Knotted String Records in Analytical Context. Taylor and Francis, 2007 pp. 93.
} 


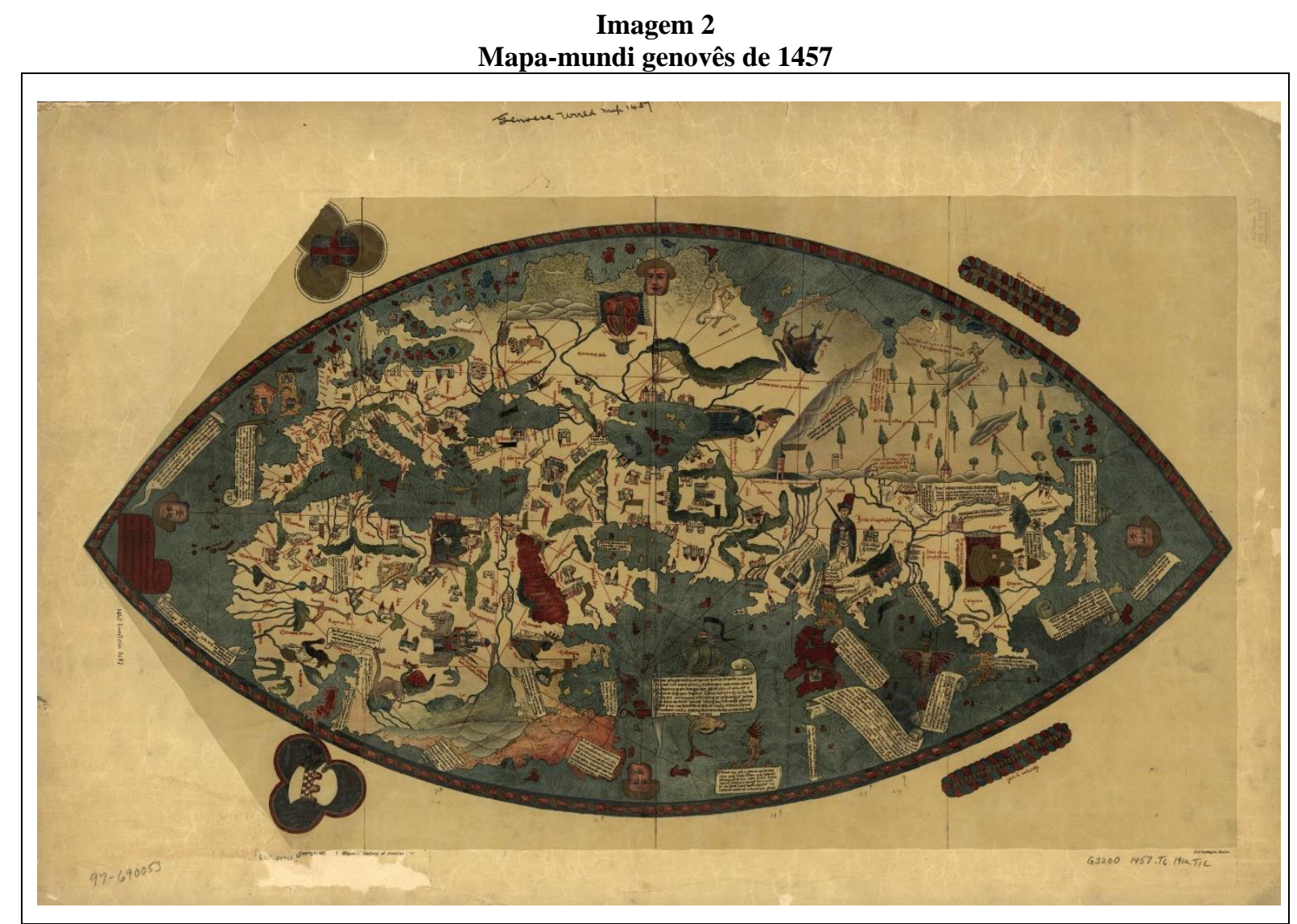

Fonte: Livraria do Congresso Norte-Americano ${ }^{20}$

Pode-se afirmar que a ruptura que houve nesse sistema é a mesma que justificou a transição da Idade Média para a Idade Moderna. Os ibéricos foram além dos censos para empregar suas políticas públicas voltadas ao ordenamento territorial. A busca de rotas seguras e rápidas às Índias, concomitante a gestão de novos territórios ultramares para a obtenção de recursos naturais e mão-de-obra barata, descortinou uma nova realidade que demonstrava as limitações dos censos nesse novo cenário, pois era um instrumento costumeiramente sem regularidade temporal, com diferentes metodologias e altamente dependente da Igreja Católica.

\section{A Era dos Mapas (de 1494 a 1854)}

Se na Era dos Censos os dados assumiam centralidade para a organização social, na Era dos Mapas a reprodução cartográfica passa a pautar o expansionismo de uma construção jurídica então neófita - os estados ocidentais ultramarinos. Pode-se convencionar que, com o Descobrimento da América, o Estado Português e o Espanhol produzem um grande marco dessa

${ }^{20}$ Ver em <https://www.loc.gov/resource/g3200.ct002087/?r=-0.172,-0.034,1.342,0.718,0>

Revista Eletrônica: Tempo - Técnica - Território, V.10, N.1 (2019), 01:51 ISSN: 2177-4366 
mudança de gestão territorial, o Tratado de Tordesilhas. ${ }^{21}$ A ausência de definição do ângulo deste meridiano no Tratado, ${ }^{22}$ concomitante a descoberta de minérios no Novo Mundo, iria fomentar as disputas entre as duas Coroas nos séculos seguintes, bem como os descaminhos que articulam cientificamente Geografia e Direito. ${ }^{23}$

Portugal alicerça seu poder com base em mapas. O Rei Manuel I, independentemente da discussão histórica da existência da Escola Naval de Sagres e de sua eventual produção cartográfica, utilizava-se da Casa da Índia e da Guiné, destinada a inventariar os produtos ultramarinos que eram monopólios da Coroa portuguesa, como o órgão responsável em produzir mapa oficial do território português ultramarino. Era o mapa exercendo sua função de dar unicidade ao território português esparramado mundo afora. ${ }^{24}$ No caso da Espanha, as necessidades administrativas eram supridas pelo censo (ou vecindarios) que, por ser então considerada de alta precisão, podia-se constituir um mapa com base nelas. ${ }^{25} \mathrm{~A}$ crise dinástica portuguesa de $1580^{26}$ diluiria essa dinâmica entre as potências ibéricas concomitante ao advento de outros estados modernos.

\footnotetext{
${ }^{21}$ Celebrado em de 7 de junho de 1494, que dividiam as terras descobertas por Cristóvão Colombo e por descobrir, com base na demarcação de meridiano localizado em 370 léguas a oeste da ilha de Santo Antão, no arquipélago de Cabo Verde.

${ }^{22}$ Em Luiz UGEDA (Direito Administrativo Geográfico - Fundamentos na Geografia e na Cartografia oficial do Brasil. Brasília: Instituto Geodireito Editora, 424p., 2017, pp. 41), destacou-se que os geógrafos Pedro Nunes (1537), João Teixeira (1542), Costa Miranda (1688), Ribeiro (1519), peritos de Badajoz (1524), Ferber (1495), Oviedo (1517) e Cantino (1502) produziram diferentes versões de onde seria o real meridiano que refletiria o Tratado de Tordesilhas. As interpretações jurídicas eram tantas que, na linha mais benéfica aos espanhóis, o Rio de Janeiro seria a fronteira colonial entre Espanha e Portugal. Na interpretação mais vantajosa aos portugueses, as atuais capitais paraguaia, uruguaia e argentina, bem como a foz do Rio da Prata, o Estreito de Magalhães, as ilhas Falkland e a Terra do Fogo seria portuguesas. Os cartógrafos pautavam o Direito, pois o instrumentalizava com suas técnicas.

${ }^{23}$ Para Mario Giuseppe LOSANO (Diritto e geografia: lo spazio del diritto e il mondo della geografia. Legal Roots: The International Journal of Roman Law, Legal History and Comparative Law, n. 1, 2012, pp. 7), esse era o exemplo mais clássico do amálgama entre direito e espaço, no qual uma pessoa que não era o proprietário - o Papa - atribuía a dois Estados soberanos o direito de propriedade sobre um bem indeterminado, isto é, sobre terras que eram em parte conhecidas e em parte a descobrir.

${ }^{24}$ Em Luiz UGEDA (Direito Administrativo Geográfico..., pp. 39), nos anos seguintes, em homenagem ao Rei Manuel I, foi publicado o Esmeraldo de situ orbis em 1506, densa obra de Duarte Pacheco Pereira que, escrito em português, codificava as coordenadas geográficas de todos os portos até então conhecidos. Importante destacar que o trabalho tinha um caráter sigiloso, documento privativo do rei, que reforça a percepção de que dados geográficos eram tratados como sinônimo de poder. Em 1519, mesmo sem Portugal dar uma destinação econômica à colônia brasileira recém-descoberta, a produção cartográfica deste território ganhava uma nova produção. Denominada inicialmente de Terra Brasilis, o Atlas Lopo Homem-Reineis, produzida pelos cartógrafos Lopo Homem, Pedro Reinel e Jorge Reinel, constituiu um documento ilustrado com uma dezena de cartas náuticas. Em relação ao censo, foi realizado um em 1527, no reinado de D. João III, identificando 1.262.376 portugueses.

${ }^{25}$ Para Carmen LÍTER, Ana HERRERO e Francisca SANCHÍS (La geografía entre los siglos XVI y XVII. Madrid, Ediciones Akal., 1996, pp. 8, Felipe II de Espanha solicitou a Pedro Esquivel, em 1566, a realização desse mapa, ordenando que todas as autoridades locais enviassem seus dados descritivos mediante um questionário minuciosamente elaborado. Tendo falecido antes de terminar a obra, assim como aconteceu com seu sucessor, Diego de Guevara, foi realizado um primeiro Atlas da Espanha com 21 mapas. Como o único registro não consta com as primeiras folhas, o autor final segue indeterminado, assim como a data de publicação.

${ }^{26}$ Mafalda Soares da CUNHA, <<A questão jurídica na crise dinástica〉>. In José MATTOSO (Org), História de Portugal: No alvorecer da modernidade (1480-1620). Editorial Estampa, 1993, pp. 552.
}

Revista Eletrônica: Tempo - Técnica - Território, V.10, N.1 (2019), 01:51 ISSN: 2177-4366 
Depois de algumas décadas com a busca de consolidação dos estados europeus, o primeiro censo moderno foi realizado por Luís XIV de França, em 1666, para resolver um problema na Nova França, hoje Canadá. Havia uma desproporção entre as populações masculina e feminina, e o recenseamento comprovou que havia 2034 homens para 1181 mulheres. ${ }^{27}$ De posse desta informação, o rei arcou com os custos de viagem e o dote de 700 mulheres para o Quebec, de maneira a colonizar o território. Essa política deu tão certo sob a ótica demográfica que a população triplicou em 15 anos.

O censo moderno ganhava novos contornos, que ultrapassavam a mera necessidade fiscal. Como exemplo, a Grã-Bretanha teve um primeiro censo em 1695, que concluiu que a população da Inglaterra e de Gales era de 5.5 milhões de pessoas. ${ }^{28}$ Em 1703 foi realizado o censo na Islândia, ${ }^{29}$ um marco por ser o primeiro a ganhar um contorno universalista, dado que buscava identificar e descrever precisamente o grande número de pobres em cada lugar, pois o critério geográfico, de espacialização e não apenas quantificação, passava a ser cada vez mais marcante. Com essa característica de vanguarda, ele foi reconhecido pela Unesco como parte da memória do mundo. Em 1749 foi a vez da Suécia seguir a mesma metodologia censitária.

A tecnicidade, por meio da Estatística e da Geografia, ganhava cada vez mais espaço enquanto instrumentos centrais de ordenamento do território. Os gestores públicos se apropriavam progressivamente de tecnologia para resolver questões mais abrangentes e complexas. A metodologia cadastral passou a ser o principal instrumento de gestão territorial, como mostraria Marquês de Pombal em Portugal, que enfrentou as consequências do Terremoto de 1755 com amplo levantamento de informações cadastrais para a reconstrução de Lisboa. ${ }^{30}$ Atribui-se aos portugueses, inclusive, a criação da expressão "cartografia". 31

\footnotetext{
${ }^{27}$ Hubert CHARBONNEAU, Jacques LÉGARÉ, La population du Canada aux recensements de 1666 et 1667. Population, $22^{\mathrm{e}}$ année, $\mathrm{n}^{\circ} 6,1967$, pp. 1037. O Censo de 1666 foi realizado por Jean-Talon, sendo que as mulheres enviadas ficaram conhecidas como as "filhas do Rei", pois eram em sua maioria mulheres do noroeste francês, órfãs, de origens modestas e criadas em conventos.

${ }^{28}$ GREAT BRITAIN PARLIAMENT. Counting the Population, Volume 1. House of Commons. Treasury Committee The Stationery Office. 2008, pp. 9.

${ }^{29}$ Em islandês, Manntalið. Ver em <skjalasafn.is/gallery/manntalid_1703>, incluindo imagem do documento produzido à época.

${ }^{30}$ Para José Augusto dos Santos ALVES, (O Marquês de Pombal e a mudança de paradigma, Cultura, Vol. 22, 177-192, 2006, pp. 183), o pragmatismo de Sebastião José entra nos domínios da sismologia moderna e da estatística demográfica, introduzindo um conjunto de premissas para estruturar o censo da população.

${ }^{31}$ Para Joaquim Alves GASPAR, (Dicionário de ciências cartográficas. Lisboa ; Porto : Lidel, 2004, pp. 72, com esse avanço científico lusitano, não por coincidência o vocábulo "cartografia" é empregado pela primeira vez pelo historiador português Manuel Francisco Carvalhosa, Segundo Visconde de Santarém, numa carta datada de 8 de Dezembro de 1839, de Paris, e endereçada ao historiador brasileiro Francisco Adolfo de Varnhagen, vindo a ser internacionalmente consagrado pelo uso. Segundo Rémy CLAIRIN (Quelques reflections sur la collecte démographique. Paris, Coopération Statéco 25, 1981, pp. 5-26), a correlação entre estatística e cartografia se
} 
Imagem 3

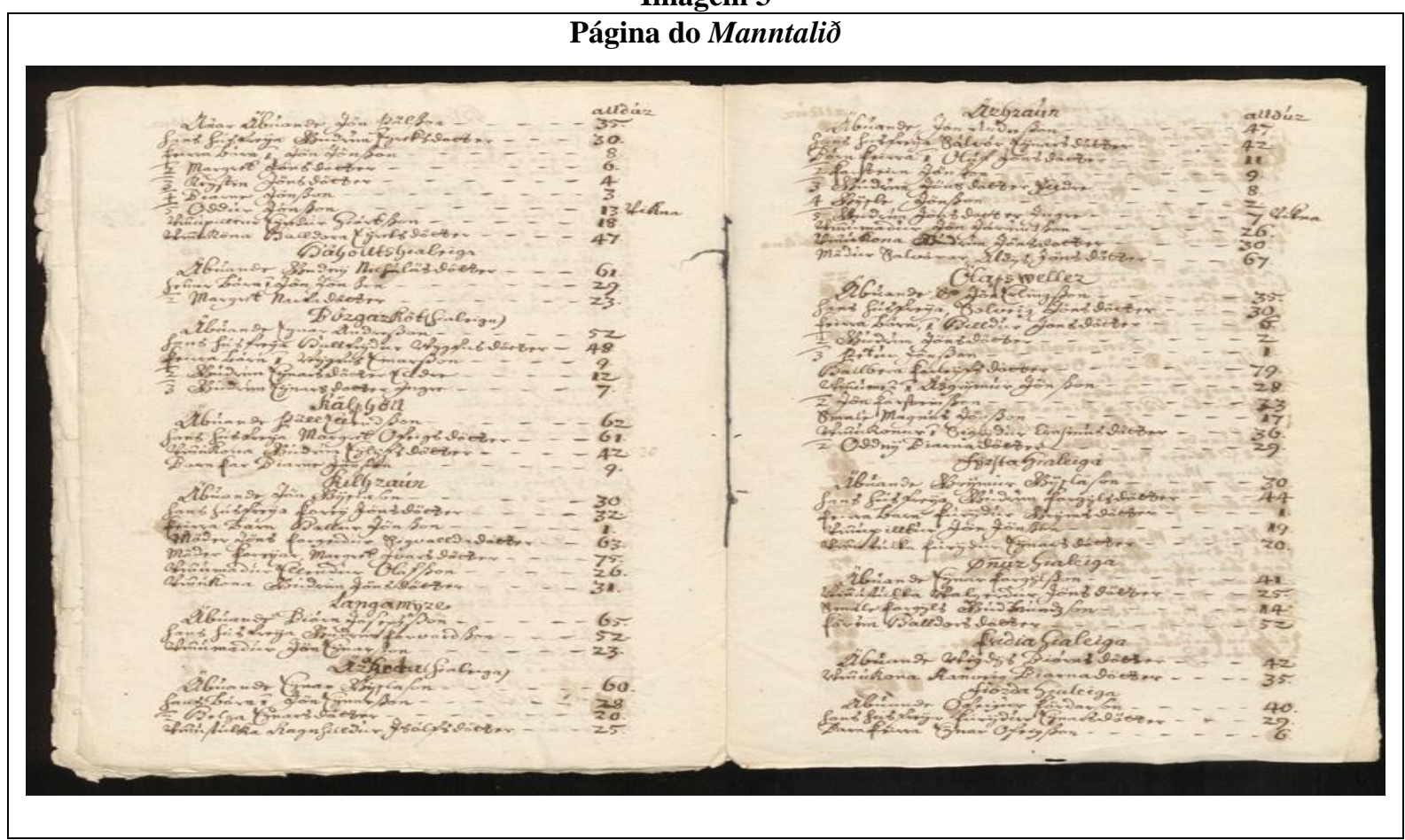

Fonte: Arquivo Nacional da Islândia ${ }^{32}$

Progressivamente, os cadastros estatísticos, com repercussão espacial e preocupação social, passaram a ser a grande inovação tecnológica para o ordenamento territorial no final do século XVIII. ${ }^{33}$ Em 1852, a China realizou o maior censo da humanidade até então, apurando mais de meio bilhão de pessoas. ${ }^{34} \mathrm{O}$ "Império do Meio" mostrava ao mundo que havia um crescimento exponencial da população em um curto período de tempo, o que para alguns estudiosos ocidentais era uma forte comprovação da teoria de Thomas Malthus, ${ }^{35}$ de que a população estava a crescer em progressão geométrica, ao passo que os alimentos cresceriam em progressão aritmética, levando o planeta à escassez de recursos. Mas o fator tecnológico, ao longo do tempo, mostraria as fragilidades da argumentação malthusiana.

Em 1853, com a realização do Congresso Internacional de Estatística em Bruxelas, ${ }^{36}$ houve a busca por uma padronização internacional dos recenseamentos, focados na fixação de uma periodicidade decenal em anos terminados em zero, mapeando as condições, os processos

tornava cada vez mais estreita, naquele período, de maneira a serem praticamente fundidas em uma única lógica. Afinal, sem uma cartografia adequada, a coleta de dados demográficos se faz no nevoeiro.

${ }^{32}$ Vide em <www.skjalasafn.is>

33 Como exemplo, em 1790, os Estados Unidos realizaram seu primeiro recenseamento, sendo seguidos pela Inglaterra (1801), Colômbia (1825), França (1836) Chile (1843) e Uruguai (1852).

${ }^{34}$ Pierre LAFFITTE, A general view of Chinese civilization and of the relations of the West with China. London, Teubnee \& Co., Ludgate Hill, 1887, pp. 62.

${ }^{35}$ Thomas MALTHUS, Essay on the Principle of population; London, John Murray, 6th edition. 1826.

${ }^{36}$ Nos anos subsequentes houve novos congressos internacionais em Paris (1855), Viena (1857), Londres (1860), Berlim (1863), de Florença (1867), de Haia (1869), de São Petersburgo (1872) e de Budapeste (1876), sempre buscando aperfeiçoar e expandir a metodologia.

Revista Eletrônica: Tempo - Técnica - Território, V.10, N.1 (2019), 01:51 ISSN: 2177-4366 
e o resultado da estatística agrícola. Censos e mapas passavam a compor uma política pública, identificados como técnicas distintas e complementares. A fusão dessas técnicas produziu uma nova ferramenta que possibilitou novo período de desbravamento tecnológico nas políticas públicas geográficas, situação que ficaria mais clara com o advento da convergência entre Estatística, Cartografia e Geografia em um único sistema.

\section{A Era dos Sistemas (de 1854 a 1992)}

A segunda metade do século XIX foi um período de grandes avanços na história da humanidade. Dentre elas, sir John Snow, considerado pai da epidemiologia moderna, aplicaria método geográfico em 1854 para promover gestão urbanística em Londres da propagação da cólera, obtendo enorme êxito e sendo, posteriormente, reconhecido como um dos fundadores do que viria a ser denominado Sistema de Informação Geográfica (SIG). Este novo ponto de inflexão nas políticas públicas geográficas evidenciaria que a produção de informações censitárias desafiava a capacidade dos estados em armazenar, processar e atualizar um volume cada vez maior de informações, de forma ágil e eficaz, para produzir cidadania.

Havia uma busca intensiva em se desenvolver novas técnicas para acelerar o processo de coleta de dados. Foi determinante, nesse quesito, a invenção de Herman Hollerith em 1884, que ao criar cartões perfurados e automatizar a obtenção de informação pessoal processou dados e possibilitou tornar mais célere a conclusão do recenseamento dos Estados Unidos de 1890. Era a lógica de se extrair informações com a maior quantidade de dados, da forma mais rápida e correta possível, possibilitando o maior número de correlações viáveis. ${ }^{37}$

\footnotetext{
${ }^{37}$ Era um período em que Portugal buscava, por intermédio de um mapa denominado "cor-de-rosa", justificar a união espacial de seus territórios continentais africanos. Para maiores informações, ver Charles NOWELL, The Rose-colored map. Portugal attempt to build an African empire from the Atlantic to the Indian Ocean. Junta de Investigações Científicas do Ultramar, Lisboa, 1982.
} 
Imagem 4

Mapa de John Snow, 1854

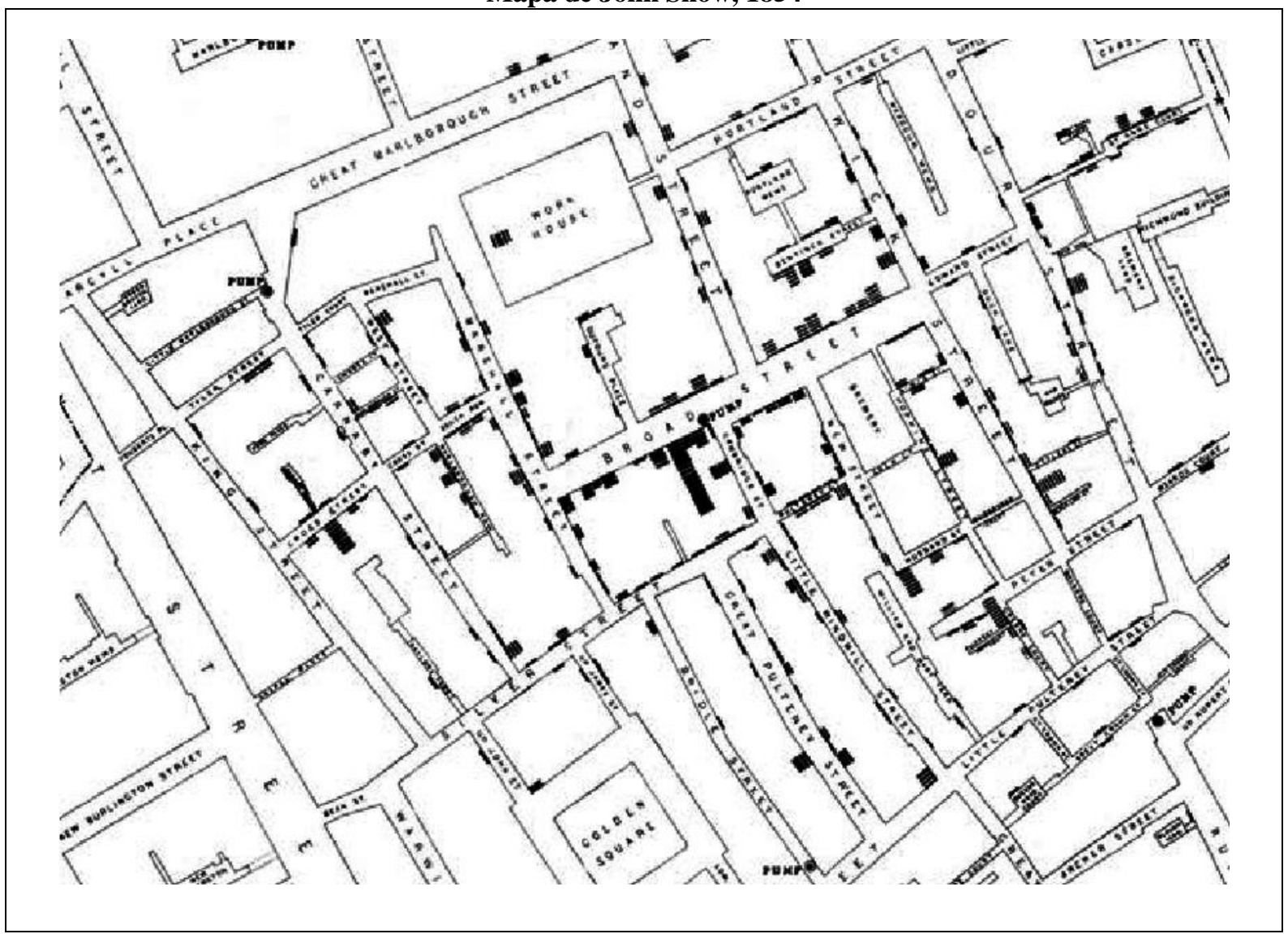

Fonte: Researchgate ${ }^{38}$

A Geografia, enquanto ramo científico, entrava em seu período clássico, momento em que se destacam a escola alemã, com a cosmologia de Humboldt, ${ }^{39}$ que promoveu uma leitura universalista da geográfica, do cosmos ao ser humano, ou mesmo Friedrich Ratzel, que correlacionou de maneira estreita Geografia e Estado, de modo a aplicar conceitos evolucionistas que, para ele, determinariam o desenvolvimento de uma nação em relação ao solo, atual ou futuro. ${ }^{40}$ De maneira a dialogar com esta construção alemã, o francês Paul Vidal de la Blache apontava a Geografia ${ }^{41}$ como uma ciência essencialmente descritiva que precisava

\footnotetext{
${ }^{38}$ Vide em <https://www.researchgate.net/figure/John-Snows-famous-map-of-the-1854-Broad-Street-epidemicattempted-to-positively_fig1_220144184>

${ }^{39}$ Alexander von HUMBOLDT, Kosmos. Entwurf einer physischen Weltbeschreibung. Bd. 4. Stuttgart u. a., 1858, pp. 32.

${ }^{40}$ Friedrich RATZEL (Der Lebensraum : eine biogeographische Studie, Tübingen : H. Laupp. 1901 pp. 47) parte do pressuposto central de que o espaço possui uma espécie de valor absoluto para as sociedades e os Estados, havendo uma aspiração natural por espaços, situação que diferencia os grandes povos e aqueles que sofrerão com o isolamento, imbuídos de miserável espírito local. Era o Espaço Vital (Lebensraum), com forte inspiração evolucionista em Charles DARWIN (On the origin of species by means of natural selection, London, John Murray, 1st edition, 1859) e que seria um ponto de inflexão para o discurso de superioridade das raças e do expansionismo nacionalista.

${ }^{41}$ Para Paul VIDAL DE LA BLACHE (Des caractères distinctifs de la Géographie. Annales De Géographie 22 124:,Paris: 1913, pp. 289.299), a Geografia deve determinar exatamente a posição que ocupam e as áreas que
}

Revista Eletrônica: Tempo - Técnica - Território, V.10, N.1 (2019), 01:51 ISSN: 2177-4366 
se voltar mais necessidades valorativas, ou axiológicas, inagurando um período de estudos regionalistas, ou "espaço de regência" do Estado perante o espaço. ${ }^{42}$

É lugar-comum na Geografia as discussões sobre o determinismo de Ratzel e o possibilismo de Vidal de la Blache. Mas analisar este debate sob a ótica das fontes científicas que essas correntes do pensamento geográfico se alimentaram talvez diga mais sobre elas do que as inesgotáveis discussões realizadas no interior da Geografia. Enquanto Ratzel realizava uma heterodoxa construção geopolítica, aliando conceitos deterministas presentes no sistema de castas indiano com o evolucionismo de Darwin, pode-se afirmar que Vidal de la Blache entendia que o Estado, entendido enquanto instância jurídica, deveria apropriar-se do espaço geográfico pelo ordenamento do território, considerando e conhecendo todas as suas características naturais e humanas. Em outras palavras, para Ratzel, o Estado era uma entidade eminentemente geopolítica; a Vidal de la Blache, o Estado era uma necessária construção geojurídica.

Na primeira metade do século XX, em que as duas grandes guerras (1914-1918 e 19391945) concentraram todas as atenções do mundo, era natural que a geopolítica estivesse no centro da atenção, sendo que uma atuação geojurídica estava mais voltada no interesse e disponibilidade de cada estado criar institutos geográficos para controlar os censos enquanto sistemas que convergiam Estatística, Cartografia e Geografia. É notório que era um ambiente extremamente polarizado ideologicamente. Todavia, é também um período em que se iniciam discussões interdisciplinares entre Geografia e Direito de forma mais estruturada, como foi o

\footnotetext{
abrangem, de maneira que nenhum índice ou nuance poderia passar despercebida, haja vista que cada uma tem seu valor geográfico, seja como dependência, seja como factor, no conjunto que se trata de analisar.

${ }^{42}$ Neste diálogo entre Ratzel e Vidal de la Blache, definidos genericamente pelo pensamento geográfico clássico, respectivamente, como determinismo alemão e possibilismo francês, os ingleses sofriam forte inspiração na escola francesa, com estruturada valorização do ordenamento territorial. Mas também havia, assim como o pensamento alemão, forte preocupação com a geopolítica. Sir Halford John MACKINDER (The Geographical Pivot of History, The Geographical Journal, v. 23, n. 4, 1904, pp. 421-437) proporia a Teoria do Heartland, que colocou em xeque o poderio militar inglês, baseado essencialmente nos mares, uma vez que o poderio marítimo teria se esgotado em função da invenção da combustão e das ferrovias transcontinentais, sendo que os esforços militares deveriam se impor para controlar o "coração da terra", ou seja, os centros físicos continentais. Logo, quem controlasse o Leste europeu tenderia a exercer o controle do mundo. Este pensamento fundamentaria os esforços nacionais nas duas grandes guerras, alicerçados no apotegma de Mackinder de que quem controla a Europa Oriental domina a Terra Central; quem controla a Terra Central, domina a Ilha Mundial; e quem controla a Ilha Mundial, domina o Mundo.
} 
caso da Geojurisprudência ${ }^{43}$ na Alemanha e do que se convencionou chamar de Law \& Geography ${ }^{44}$ na realidade anglo-saxã.

Após a Segunda Grande Guerra (1939-1945), momento em que se busca sepultar a guerra por meio de uma nova ordem mundial, houve o nascimento da Organização das Nações Unidas (ONU) em 24 de outubro de 1945. Tendo sido fundada por 51 países, sucedeu a Liga das Nações, promovendo formas de relacionamento internacional em um ambiente pós-Segunda Grande Guerra e com a necessidade de equacionar o desequilíbrio global ocasionado pelo desenvolvimento da bomba nuclear, que produziu significativos impactos no conceito de soberania dos estados. Com a criação de uma instância global, passa-se a haver uma grande discussão sobre governança global e formas de interação entre sistemas jurídicos distintos. É possível afirmar que a Geografia se transforma na base de estudos de direito comparado, como demonstra a corrente francófona do Géographie $d u$ Droit ${ }^{45}$ que teve ampla repercussão nos então denominados países do então denominado terceiro mundo, cabendo uma especial menção, pela densidade e profundidade, a obra do brasileiro José Nicolau dos Santos. ${ }^{46}$

Na segunda metade do século XX, houve duas rupturas nesta forma de se pensar e se instrumentalizar a interdisciplinaridade. Por um lado, os geógrafos e os juristas passaram a adotar um conteúdo político-ideológico, que passou a edificar sua construção basicamente no marxismo, na Teoria Crítica da Escola de Frankfurt, no anarquismo e no pós-modernismo. A partir da década de 1970 a corrente do Law \& Geography ganha densidade sob esta perspectiva. $^{47}$

${ }^{43}$ Com pioneirismo, o então jovem jurista alemão Manfred LANGHANS-RATZEBURG (Geopolitik und Geojurisprudenz. Jena, Frommannsche Buchhandlung - W. Biedermann, 1932, pp. 33-34) elaborou estudo sobre o que chamou de Geojurisprudência, ou seja, a Jurisprudência deveria ser para o Direito o que a Geopolítica era para a Geografia. Essa proposta de diálogo entre Geografia e Direito deveria formar um ramo da ciência jurídica que explicasse e ilustrasse os resultados da investigação jurídica mediante um tratamento geográfico e cartográfico. ${ }^{44}$ Derwent WHITTLESEY (The Impress of Effective Central Authority upon the Landscape. Annals of the Association of American Geographers. v. 25, n. 2, p. 85-97. 1935, pp. 90), considerado um dos pioneiros do que viria a ser o Law \& Geography anglo-saxão, versava sobre as causas e consequências da modificação da paisagem pelo Direito.

${ }^{45}$ Nomes como Max SORRE (Les fondements de la Géographie Humaine". Paris : Librarie Armand Colin, 1950) e René DAVID (Géographie juridique, Encyclopédie de la Pléiade, Géographie générale, Paris, Gallimard, 1966, p. 1738-1748) passam a estudar diversos sistemas jurídicos e correlacionar Direito e espaço, na busca de um equacionamento e conformação de diversos sistemas em função da governança global.

${ }^{46}$ José Nicolau DOS SANTOS (Geografia humana e teoria geral do Estado. Ciências correlatas. Curitiba: Ed. Guaíra, 1951; ONU - Estado, Proto-Estado ou Super-Estado? Curitiba: Ed. Guaíra, 1952; Fundamentos da Geografia Jurídica. Revista da Faculdade de Direito do Paraná, Paraná, v. 2, p. 174-261, 1954; e Direito Comparado e Geografia Jurídica. Revista da Faculdade de Direito. Universidade do Paraná, Curitiba, ano 3, n. 3, 1955).

${ }^{47}$ Rutherford PLATT (Land Use Control: Interface of Law and Geography. Washington: Association of American Geographers, 1976) criou modelos de estudo fundados na paisagem e no controle da terra, tendo formado uma série de autores nas décadas seguintes. Boaventura de Souza SANTOS (Uma cartografia simbólica das representações sociais: Prolegómenos a uma concepção pós-moderna do direito. Revista crítica de Ciências Sociais, n. 24. Coimbra, 1988) versa sobre mapas e normas enquanto sistemas de referência. Nicholas BLOMLEY, David DELANEY e Richard FORD (The Legal Geographies Reader, New Jersey: Blackwell Publishers, 2001) fomentaram a discussão de maneira didática, e demonstraram formas de interação disciplinar; e Jane HOLDER e

Revista Eletrônica: Tempo - Técnica - Território, V.10, N.1 (2019), 01:51 ISSN: 2177-4366 


\section{Imagem 5}

Imagem do LANDSAT-1 de alagamento do rio Mississippi em 1973

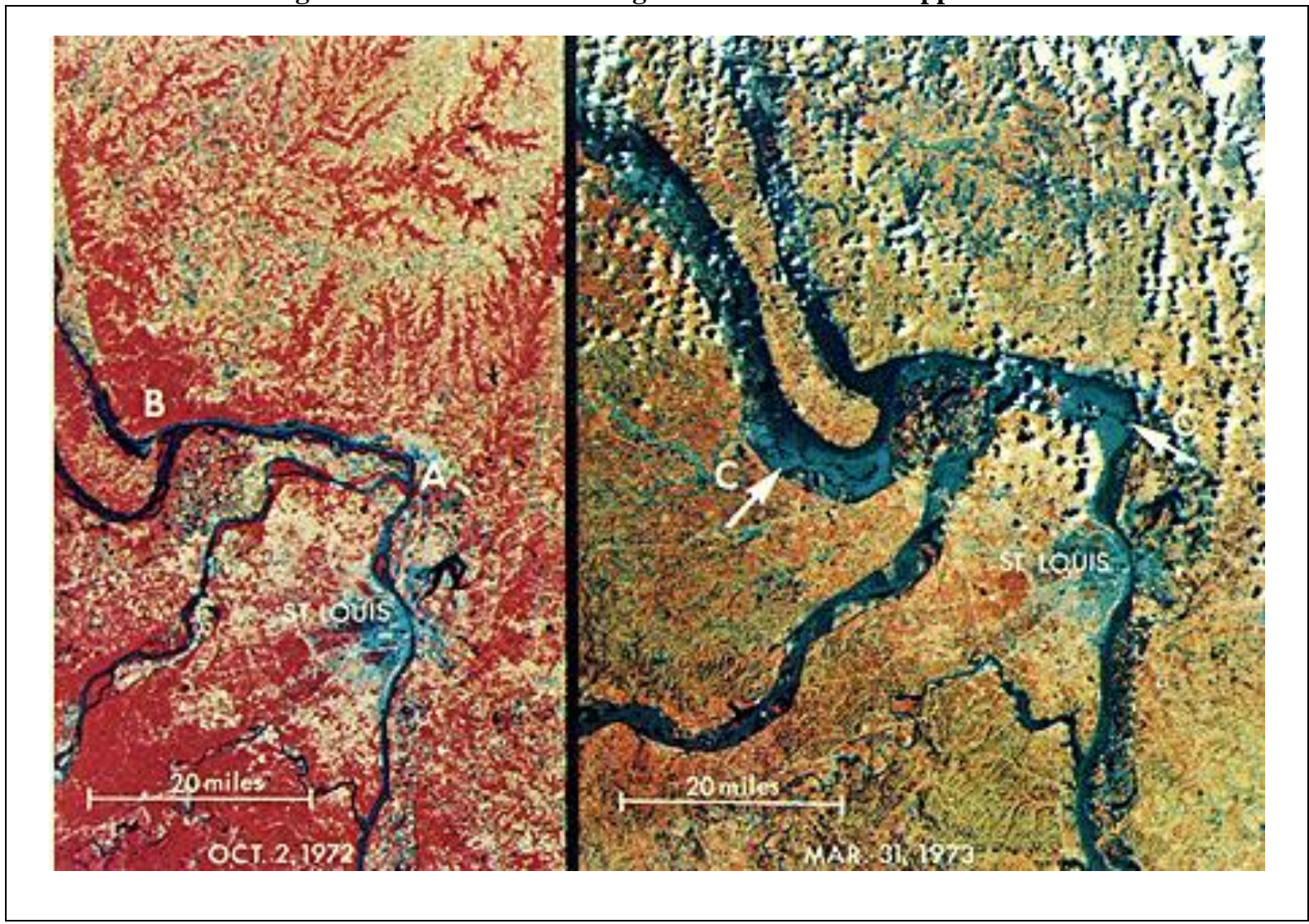

Fonte: Federação dos Cientistas Norte-Americanos ${ }^{48}$

Por outro lado, as tecnologias davam uma nova guinada nos rumos da Geografia. Decorrente da corrida espacial, momento em que vários tratados internacionais foram firmados por meio da ONU, ${ }^{49}$ e o fato de que três astronautas americanos conseguirem pousar na Lua, em 20 de julho de 1969, ocorreram grandes avanços na observação da Terra por meio de sensoriamento remoto espacial, de maneira a possibilitar informações geoespaciais. O programa Landsat, ${ }^{50}$ realizado pelos Estados Unidos por intermédio da Nasa,${ }^{51}$ construiu uma sequência de satélites ${ }^{52}$ que possibilitaram incrementar os sistemas de informação geográficas

Carolyn HARRISON, (Law and Geography. Oxford University Press, vol. 5, 2003), trataram da inter-relação da Geografia em diversos ramos do Direito.

${ }^{48}$ Vide em <www.fas.org>

${ }^{49}$ Como exemplo, o Acordo sobre Salvamento de Astronautas e Restituição de Astronautas e Objetos lançados ao Espaço Exterior, de 22 de abril de 1968; o Tratado sobre Princípios Reguladores das Atividades dos Estados na Exploração e Uso do Espaço Cósmico, inclusive a Lua e demais Corpos Celestes; e a Convenção sobre Responsabilidade Internacional por Danos Causados por Objetos Espaciais.

${ }^{50}$ Nomenclatura do principal programa de satélites de observação da Terra naquele período histórico, de origem norte-americana.

${ }^{51}$ Referimos ao National Aeronautics and Space Administration, em <www.nasa.gov〉.

52 Em 1972, 1975 e 1978. 
com imagens espaciais, que quando dispostas em sistema compõe um modelo fulminante de observação terrestre. Essa tecnologia, somada aos aerolevantamentos, ao advento da internet, ao Big Data e a computação ubíqua ocasionaram uma nova fase no ordenamento territorial.

\section{A Era da Geoinformação (desde 1992)}

Com a revolução tecnológica ocorrida principalmente nas duas últimas décadas do século $\mathrm{XX}$, os censos, os mapas, os sistemas geográficos e as informações geoespaciais passavam a compor uma grande evolução em relação aos sistemas anteriores. Afinal, passou a ser possível criar modelos em três dimensões, multiescalares, com a possibilidade de cumular camadas (layers) praticamente de forma infinita. Com este grau de sofisticação, restava identificar como estas atividades poderiam instrumentalizar políticas públicas geográficas.

Considerada esta realidade, a Conferência das Nações Unidas para o Meio Ambiente e Desenvolvimento (Rio 92), ocorrida no Rio de Janeiro entre 3 e 14 de junho de 1992, destinada a debater os problemas ambientais mundiais, criou um marco regulatório global para o desenvolvimento das políticas públicas geográficas, ou seja, como cada Estado de Direito viria conceber suas técnicas enquanto bem de domínio público.

A padronização de dados passou a compor uma premissa imperiosa do desenvolvimento dos Estados mundo afora, devendo ser aprimorados qualitativamente, situação que fundamentou a criação de Infraestrutura de Dados Espaciais (IDE) como peça fundamental da política pública geográfica de um país. ${ }^{53}$ Importante destacar que a compatibilização de formatos de dados ou interoperabilidade também foi abordada pela Agenda 21, pois são imprescindíveis para obter indicações adequadas de sustentabilidade. ${ }^{54}$ As bases do

\footnotetext{
${ }^{53}$ A IDE deve ser composta por (i) dados, sendo classificados em dados de referência (como mapeamento básico cadastral, localidades, limites, dentre outros) e dados temáticos (cobertura e uso da terra, serviços públicos, transportes, por exemplo); (ii) metadados, que documentam e registram os dados, permitindo a sua busca e localização; e (iii) geoserviços, como funcionalidades que uma Infraestrutura de Dados Espaciais (IDE) oferece aos usuários finais para acessar dados e metadados geoespaciais, permitindo a visualização de mapas, seu download, consulta, conversão, dentre outros, por meio de aplicações web ou de gabinete (Luiz UGEDA, Direito Administrativo Geográfico..., pp. 246).

54 Conforme estabelecido no item 7.33. da Agenda 21, todos os países, especialmente os países em desenvolvimento, sozinhos ou em agrupamentos regionais ou sub-regionais, devem obter acesso às técnicas modernas de manejo dos recursos terrestres tais como sistemas de informações geográficas, imagens/fotografias feitas por satélite e outras tecnologias de sensoriamento remoto. No item 14.41., os Governos, no nível apropriado, com o apoio das organizações internacionais e regionais competentes, devem: (i) desenvolver bases de dados e sistemas de informação geográfica para armazenar e fornecer informações físicas, sociais e econômicas relativas à agricultura, e para a definição de regiões ecológicas e áreas de desenvolvimento; (ii) selecionar combinações de usos da terra e sistemas de produção adequados às unidades territoriais por meio de procedimentos de otimização das metas múltiplas e fortalecer os sistemas de execução e a participação das comunidades locais; e (iii) estimular o planejamento integrado no nível das bacias e paisagens específicas para reduzir a perda de solo e proteger os recursos hídricos de superfície da poluição química.
} 
desenvolvimento geoespacial, que passariam a ser tratadas pelos governos mundo afora no século XXI, estavam lançadas. E estes conceitos foram aprimorados nas cúpulas subsequentes, ${ }^{55}$ obtendo formas de padronização. ${ }^{56}$

Por sua vez, a iniciativa privada promoveu enormes avanços no aprimoramento de tecnologias geoespaciais. O advento do Google Maps, em fevereiro de 2005, programa computacional que mapeia, em escalas grandes e pequenas, o globo terrestre com base em imagens espaciais, concomitante à viabilização do Google Earth ${ }^{57}$ alterou a maneira de compreender os diferentes territórios mundo afora. Seu módulo básico, aliada a qualidade e atualidade de suas informações, possibilitou uma leitura tridimensional do globo terrestre com base em sobreposição de imagens de satélite, aerolevantamento e sensoriamento remoto, quebrando um paradigma milenar: transformaram os mapas em commodities.

Sua massificação não tardaria para ser utilizada em políticas públicas, devido à qualidade de suas informações, às lacunas na edificação das políticas públicas geográficas nos diversos países, bem como a proliferação do emprego de softwares livres e de dados abertos para produção de informação geográfica. Vejamos como esse conjunto de ferramentas tem se transformado em infraestrutura de dados espaciais.

\section{A INFRAESTRUTURA DE DADOS ESPACIAIS (IDE) COMO BASE TÉCNICA DA INTERDISCIPLINARIDADE ENTRE GEOGRAFIA E DIREITO}

A Geografia Clássica nos ensina que o solo é um fator de produção primário, sem a qual não se pode desenvolver qualquer atividade econômica. Ordená-lo significa obter condições objetivas de reduzir pobreza e obter coesão social. O registro da terra, aprimorado com o

\footnotetext{
No que concerne a meta 40.9, os centros nacionais e internacionais de dados e informações devem estabelecer sistemas contínuos e acurados de coleta de dados e utilizar os Sistemas de Informação Geográfica (SIG) para a avaliação e análise de dados, haja vista a necessidade de se processar uma grande quantidade de dados obtidos por meio de fontes de satélites no futuro.

${ }^{55}$ Entre 26 de agosto a 4 de setembro de 2002, foi realizada a Rio+10, ou a Cúpula de Johannesburgo, na África do Sul. Ela reconheceria as afirmações realizadas na Cimeira da Rio 92, sendo seguida por todas as reuniões seguintes, referentes a importância dos dados baseados em tecnologia espacial, o emprego da informação geoespacial fidedigna para a formulação de políticas públicas enquanto pressuposto de construção de projetos de desenvolvimento sustentável, bem como a importância da cartografia e a necessidade de se apoiar os países em desenvolvimento nesta frente. Nos meses seguintes, ocorreu a Conferência das Nações Unidas sobre Desenvolvimento Sustentável, a Cimeira da Rio+20, realizada no Rio de Janeiro de 13 a 22 de junho de 2012, com resultados bem mais tímidos do que a Rio 92, e com enfoque maior para a questão de segurança e terrorismo.

${ }^{56}$ Para João MATOS (Fundamentos de Informação Geográfica. LIDEL - Edições Técnicas, $1^{\text {a }}$ Edição, Lisboa, 2008, pp. 260), acompanhando esta tendência global, a ISO - International Organization for Standardization criou uma série de normativos para padronizar as informações geográficas.

${ }^{57}$ Mediante a aquisição em 2004 da empresa Keyhole, Inc., pela Google, que iniciou as pesquisas em 2001.
} 
desenvolvimento tecnológico, funciona como um grande repositório para informações sobre o terreno, formando um estruturado cadastro, que deve ser utilizado tanto pelo poder público quanto pela iniciativa privada.

Em um período em que latitude e longitude passam a ter sinalização econômica, há uma corrida internacional pelo domínio da infraestrutura geográfica global. Se o sistema de posicionamento global norte-americano, mais conhecido pela sigla GPS ${ }^{58}$ foi pioneiro nesse sentido, é preciso destacar que a União Europeia tem desenvolvido seu sistema próprio, o Galileo; a Rússia o Glonass; e a China o Compass (Beidou). Dominar o "onde" da civilização significa ter a capacidade de espacializar a internet e, por conseguinte, ter condições objetivas de antever os movimentos das diversas sociedades.

A globalização se retroalimenta do Big Data e das ferramentas geoespaciais. A massificação do acesso à tecnologia geográfica decorrente da proliferação de smartphones viabiliza rápido acesso a diversas formas de mapas, e todos estes elementos em conjunto moldam o estilo de vida neste início de século. Em regra, os governos tem buscado desenvolver suas respectivas infraestruturas com base em quatro eixos: (i) conceber uma governança própria, que possibilite otimizar os benefícios dos recursos geoespaciais das entidades governamentais, evitando a aquisição de imagens iguais para finalidades distintas; (ii) assegurar a qualidade dos dados, de forma a desenvolver formas de obtenção, preservação, manutenção e disseminação, criando uma hierarquização apropriada entre dados abertos, reservados e sigilosos; (iii) garantir fácil acesso, de maneira que eles possam ser facilmente descobertos, avaliados e acessados; e (iv) possibilitar a interoperabilidade, possibilitando que os conjuntos de dados geoespaciais, serviços e sistemas de propriedade do governo possam ser combinadas e reutilizados para fins múltiplos.

Neste contexto, uma infraestrutura de dados espaciais (IDE) constitui-se em um conjunto articulado de tecnologias, políticas, arranjos institucionais, recursos e procedimentos de trabalho padronizado, cujo objetivo principal é assegurar a cooperação entre diferentes instituições para dotar um país de um sistema de informação geográfica. ${ }^{59}$ Uma IDE vai muito além da simples disponibilização de dados, uma vez que deve ser um mecanismo de utilização intuitiva e simples. Ela segue duas diretrizes internacionais: o Consórcio Geoespacial, ${ }^{60}$

\footnotetext{
${ }^{58}$ Referimos ao Global Positioning System.

59 Informação geográfica é um elemento essencial para o desenvolvimento de territórios, o uso racional dos recursos, bem como a conservação do meio ambiente e a qualidade de vida das sociedades, principalmente uma ferramenta de importância nos processos de tomada de decisão. A IDE fornece uma base para a pesquisa, avaliação e utilização da informação geográfica para usuários e geradores de todos os níveis da administração, comercial, organizações sem fins lucrativos, universidades e cidadãos em geral.

${ }^{60}$ Referimos ao Open Geospatial Consortium (OGC), em <www.opengeospatial.org>.
}

Revista Eletrônica: Tempo - Técnica - Território, V.10, N.1 (2019), 01:51 ISSN: 2177-4366 
responsável pela definição de normas abertas que permitem a interoperabilidade dos diferentes sistemas e facilitam o intercâmbio de informação geográfica para o benefício dos usuários; e o Comité Técnico da Organização Internacional de Normalização, ${ }^{61}$ que gera padrões mínimos para viabilizar a interoperabilidade. Abaixo identificaremos como cada um dos continentes tem se dedicado ao tema, listando países por região, que estarão em ordem alfabética. Sua escolha foi realizada de maneira a mesclar países com distintas extensões territoriais, com modelos de governança diferentes e foram dispostos em caráter amostral.

\section{IDE na Europa}

O continente europeu compreende a península ocidental da Eurásia, situando-se a oeste dos montes Urais, ao sul do oceano Glacial Ártico, ao norte do mar Mediterrâneo e a leste do oceano Atlântico. Tem em torno de $10.180 .000 \mathrm{~km}^{2}$, compreendendo cerca de 50 países que contempla uma população de 740 milhões de habitantes. ${ }^{62}$ Dentre suas inúmeras subdivisões, há um conjunto de 28 países ${ }^{63}$ que formam a União Europeia e que criaram em 2001 a iniciativa INSPIRE $^{64}$ para promover a disponibilização de informação geoespacial às suas políticas públicas, com um conjunto robusto de legislações específicas sobre o tema, principalmente

\footnotetext{
${ }^{61}$ ISO/TC 211 Geographic information/Geomatics, disponível em <www.iso.org/committee/54904.html>.

${ }^{62}$ Dados notórios disponibilizados em <www.worldatlas.com>. População referente a 2015.

${ }^{63}$ Incluindo a Grã-Bretanha, em processo de desligamento (Brexit).

${ }^{64}$ Referimos a Infrastructure for Spatial Information in the European Community. Criada pela Diretiva 2007/2/EC do Parlamento Europeu e do Conselho de 14 de março de 2007, que estabeleceu a criação da Infraestrutura Europeia de Informação Geográfica, obrigando os Estados-Membros a gerirem e a disponibilizarem os dados e os serviços de informação geográfica de acordo com princípios e regras comuns. Este tema foi regulamentado pelo Regulamento (CE) n. ${ }^{\circ}$ 1205/2008. Os três anexos da Diretiva abrangem 34 categorias temáticas de dados geográficos. O anexo I inclui as categorias temáticas de dados de base como, por exemplo, os sistemas de referência, endereços, parcelas cadastrais e redes de transporte. $\mathrm{O}$ anexo II inclui as categorias temáticas de dados geográficos como, por exemplo, a altitude e a ocupação do solo. O anexo III abrange as categorias de dados sobre ambiente, saúde e energia como, por exemplo, as instalações de monitorização, as instalações industriais, agrícolas ou aquícolas, as zonas de risco natural, os habitats ou os recursos energéticos.
} 
sobre metadados ${ }^{65}$ interoperabilidade,${ }^{66}$ serviços de rede, ${ }^{67}$ partilha de dados e serviços, ${ }^{68}$ bem como monitoração e apresentação de relatórios. ${ }^{69}$

A Diretiva INSPIRE significou um enorme avanço na governança geográfica europeia. Como exemplo, em 2007 havia apenas 1384 dados geográficos identificados, sendo que em 2013 este número saltou para mais de 56 mil. ${ }^{70}$ Mas esta rica produção de dados foi desigual no território. Oito Estados-membros produziram mais de $90 \%$ dos dados, sendo que os outros vinte Estados-membros tiveram menos de 10\% desta produção. Outro problema identificado no fomento do livre fluxo da geoinformação foram as complexas e heterogêneas políticas nacionais em matéria de dados, bem como a ausência de uma política pan-europeia neste domínio. Analisemos como alguns países se relacionaram perante esta realidade.

A Alemanha, enquanto Estado-membro da União Europeia, conta com uma lei federal, diversas bases para o acesso a dados e uma Agência Federal de Cartografia e Geodésia ${ }^{71}$ que produz modelos digitais de terreno e os mapas topográficos digitais em escalas abrangentes, que variam de 1:1.000.000 até 1:25.000. Todavia, o levantamento e o mapeamento são uma tarefa dos 16 estados federados, que contam com seus respectivos serviços topográficos e cadastrais. Tradicionalmente a coleta de dados é amplamente descentralizada e realizada principalmente em nível regional e local, que significa que o processamento e manutenção de dados é mais adaptado às necessidades locais e regionais, que leva a uma certa incompatibilidade quando reúne os demais dados ${ }^{72}$ no Geoportal. ${ }^{73}$

\footnotetext{
${ }^{65}$ Vide Regulamento (CE) No 1205/2008 da Comissão de 3 de dezembro de 2008, que estabelece as modalidades de aplicação da Diretiva 2007/2/CE do Parlamento Europeu e do Conselho em matéria de metadados, bem como o Corrigendum to INSPIRE Metadata Regulation, de 15/12/2009.

${ }^{66}$ Vide Regulamento (UE) No 1089/2010 da Comissão de 23 de Novembro de 2010, que estabelece as disposições de execução da Diretiva 2007/2/CE do Parlamento Europeu e do Conselho relativamente à interoperabilidade dos conjuntos e serviços de dados geográficos; e Regulamento (UE) No 102/2011 da Comissão de 4 de Fevereiro de 2011, que altera o Regulamento (UE) n. 1089/2010, que estabelece as disposições de execução da Diretiva 2007/2/CE do Parlamento Europeu e do Conselho relativamente à interoperabilidade dos conjuntos e serviços de dados geográficos.

67 Vide Regulamento (UE) N ${ }^{\circ}$ 1088/2010 da Comissão de 23 de Novembro de 2010 que altera o Regulamento (CE) $n^{\circ} 976 / 2009$, no que respeita aos serviços de descarregamento e aos serviços de transformação; e o Regulamento (CE) N 976/2009 da Comissão de 19 de Outubro de 2009, que estabelece as disposições de execução da Diretiva 2007/2/CE do Parlamento Europeu e do Conselho no que respeita aos serviços de rede.

${ }^{68}$ Vide Regulamento (UE) No 268/2010 da Comissão de 29 de março de 2010, que estabelece as modalidades de aplicação da Diretiva 2007/2/CE do Parlamento Europeu e do Conselho no que respeita ao acesso, em condições harmonizadas, das instituições e órgãos comunitários aos conjuntos e serviços de dados geográficos dos Estados/Membros.

${ }^{69}$ Vide Decisão da Comissão de 5 de junho de 2009, que estabelece as disposições de execução da Diretiva 2007/2/CE do Parlamento Europeu e do Conselho em matéria de monitorização e apresentação de relatórios.

${ }^{70}$ Ver em <www.inspire.ec.europa.eu>.

${ }^{71}$ Referimos ao Bundesamt für Kartographie und Geodäsie em <www.bkg.bund.de>.

72 Ino AUGSBERG, Informationsverwaltungsrecht. Zur kognitiven Dimension der rechtlichen Steuerung von Verwaltungsentscheidungen, Tübingen, 2014, pp. 34.

${ }^{73}$ Referimos ao Geodaten aus Deutschland em <www.geoportal.de〉.
}

Revista Eletrônica: Tempo - Técnica - Território, V.10, N.1 (2019), 01:51 ISSN: 2177-4366 
A primeira legislação relativa a infraestrutura de dados espaciais na Croácia entrou em vigor em fevereiro de $2007 .{ }^{74} \mathrm{Um}_{\text {capítulo especial }}{ }^{75}$ definiu a IDE, sua criação e manutenção, implementou um quadro institucional e suas responsabilidades, versou sobre metadados e pormenorizou questões como o cadastro imobiliário. Em 2009, a Diretiva INSPIRE foi incluída pela primeira vez no programa nacional para a adesão da União Europeia, sendo que a transposição da Diretiva INSPIRE foi monitorizada até a entrada da Croácia ser efetivada em 2013. De forma adicional a iniciativa INSPIRE, a Croácia adotou normas nacionais sobre o tema. ${ }^{76}$

Na Escandinávia, a Dinamarca tem uma iniciativa na IDE que cria uma cooperação intergovernamental em três níveis administrativos, incluindo a Groelândia e as ilhas Faroe. No governo central, o Ministério do Meio Ambiente tem a responsabilidade principal de gerir este setor por meio da Agência Dinamarquesa de Geoinformação. ${ }^{77}$ As cinco regiões e os 98 municípios também contribuem diretamente para o desenvolvimento da IDE. O cadastro dinamarquês, ligado a Agência Dinamarquesa de Geoinformação, é a base para todos os registros de terra no país, desenvolvendo um mapa cadastral, um registro oficial e um arquivo cadastral, tendo papel central na gestão pública e administração da propriedade da terra. ${ }^{78}$

A Infraestrutura de Dados Espaciais de Espanha (IDEE) é um projeto coordenado pelo Conselho Superior Geográfico (CSG), que orienta o Instituto Geográfico Nacional, ligado ao Ministério do Fomento, no objetivo de integrar dados, metadados, serviços e toda a informação geográfica produzida no país, fornecendo os potenciais de localização de usuários, identificação, seleção e acesso a esses recursos por meio de seu geoportal. A Espanha, seguindo

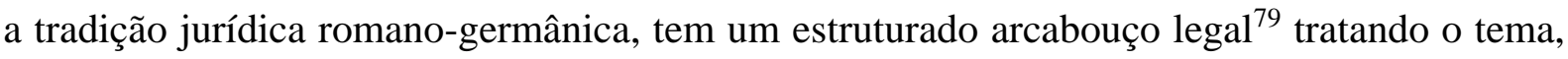

\footnotetext{
${ }^{74}$ Diário Oficial de 16 de julho.

${ }^{75}$ Capítulo V

${ }^{76}$ Vide normas de execução para metadados (Gazeta Oficial - OG 102/10); e a implementação de regras para os serviços de rede (Gazeta Oficial - OG 46/12).

${ }^{77}$ Referimos a Geodatastyrelsen em <www.eng.gst.dk>.

78 Atualizações para cadastro da Dinamarca são realizadas com o uso de duas ferramentas digitais, a MIA e o miniMAKS. Topógrafos credenciados têm tradicionalmente realizado o trabalho de campo relacionado com registro de terra e, por meio da MIA, apresentaram casos a Agência Dinamarquesa de Geoinformação. O sistema miniMAKS apresenta os dados preparados por topógrafos credenciados e permite que os funcionários da Agência Dinamarquesa de Geoinformação verifiquem as aprovações pertinentes.

${ }^{79}$ Vide a Lei 14/2010, de 5 de julho, que cria a infraestrutura e serviços de informação geográfica; a Lei 11/1975, de 12 de março, que trata da Geodésica e dos sinais geofísicos; a Lei 37/1988 de 28 de dezembro (art. 122), que cria o Centro Nacional de Informação Geográfica; a Lei 7/86, de 24 de janeiro, que trata do gerenciamento do mapeamento; a FOM/2807/2015, de 18 de dezembro, que aprova a política de divulgação pública da informação geográfica gerada pela Direção-Geral do Instituto Geográfico Nacional; o Real Decreto 1071/2007, de 27 de julho, que regula o sistema geodésico de referência oficial; o Real Decreto 1545/2007 de 23 de novembro, que regula o sistema nacional de mapeamento; o Real Decreto 1637/2009 de 30 de outubro, que altera os estatutos do Centro
} 
podendo ser considerada uma das grandes referências globais sobre a matéria, dada a maturidade de sua governança geoespacial.

A França possui uma longeva tradição em mapeamento para gestão pública. Desde a produção de mapas pela família Cassini no século XVIII, ${ }^{80}$ passando pelos mapas militares de Napoleão I, a criação do Instituto Geográfico Nacional (IGN) ${ }^{81}$ em 1940 possibilitou a produção e a manutenção de informações geográficas para a França e seus departamentos ultramarinos. Atualmente, as iniciativas governamentais para desenvolver uma IDE na França ainda são limitadas, em que pese o IGN manter seu protagonismo no mapeamento do território ${ }^{82}$ e ter sido lançado um geoportal em 2006.

A Holanda regulamenta a IDE por meio de um Conselho de Informação Geográfica, que é o mais alto órgão consultivo administrativo nos Países Baixos. Neste Conselho ${ }^{83}$ estão representadas a maioria das organizações governamentais (ministérios, províncias, municípios, autoridades de água e agências governamentais). Para gerir as informações, o país escolheu o modelo de fundação, criada em 2007 sob o nome de Geonovum,${ }^{84}$ que absorveu, dentre outras tarefas, o fornecimento de melhor acesso à geoinformação do setor público, incluindo o cadastro imobiliário. O Ministério da infraestrutura e do Meio Ambiente é o responsável pela IDE holandesa. ${ }^{85}$

A legislação ${ }^{86}$ da Itália atribui ao Ministério do Conselho Nacional a capacidade de gerir a informação espacial e ambiental, bem como a coordenação direta de todas as partes interessadas, com o objetivo de viabilizar o funcionamento eficaz dos diferentes níveis de administração de infraestrutura nacional de informação geográfica e de monitoramento

\footnotetext{
Nacional de Informação Geográfica, aprovado pelo Real Decreto 663/2007, de 25 de maio; o Real Decreto 2421/1978, de 2 de junho, que aprova o Regulamento da Lei 11/1975, de 12 de março (sinais geodésicos e geofísicos); o Real Decreto 2724/1998, de 18 de dezembro, que trata da integração dos serviços regionais da Direção Geral do Instituto Geográfico Nacional, nas delegações do governo; o Real Decreto 663/2007 de 25 de maio, que aprova o estatuto do Centro Nacional de Informação Geográfica; e a Resolução de 1 de julho de 2004, do Centro Nacional de Informação Geográfica, que estabelece os preços públicos que regulam a distribuição de dados, publicações e serviços de natureza geográfica.

${ }^{80} \mathrm{O}$ "mapa de Cassini" é considerado o primeiro mapa geral do Reino da França, tendo sido elaborado por CésarFrançois Cassini de Thury (Cassini III) e seu filho Jean-Dominique Cassini (Cassini IV) - durante o século XVIII. A escala adotada foi 1:86.400. Ver em <www.ign.fr>.

${ }^{81}$ Referimos ao Institut national de l'information géographique et forestière (IGN) em <www.ign.fr>.

${ }^{82} \mathrm{O}$ IGN cobre o território francês com mapas topográficos em escalas de 1:100.000 a 1:25.000; autoestradas em escalas de 1:250,000 a 1:1,000,000; bem como cartas aeronáuticas em escala de 1:500.000. O IGN também é responsável pelo Geoportal (Referimos ao Géoportail em <www.geoportail.gouv.fr>).

${ }^{83}$ Denominado Geographic Information Board, ou GI-Board.

${ }^{84}$ Vide em <www.geonovum.nl>.

${ }^{85} \mathrm{O}$ armazenamento e a manutenção dos dados é regulada em legislação e os dados consistentes, aderindo às especificações de dados através do registro. Os usuários são obrigados a comunicar informações incorretas aos produtores, e há uma política rigorosa garantia de qualidade. Os registros podem chegar de escalas em até 1:500. O setor de geoinformação holandês gera pelo menos 1,5 biliões de Euros/ano e emprega 15 mil pessoas.

${ }^{86}$ Vide art. 11 do Decreto Legislativo n. 32/2010.
}

Revista Eletrônica: Tempo - Técnica - Território, V.10, N.1 (2019), 01:51 ISSN: 2177-4366 
ambiental. O modo de funcionamento do Conselho Nacional de informações territoriais e ambientais são definidas em decreto. ${ }^{87}$ Dentre outros órgãos, participam o Instituto Geográfico Militar; o Instituto Hidrográfico de Marinha; o Centro de Informação Geotopográfica da Aeronáutica; a Agência de Registro de Terras e Cartografia; e o Instituto de Pesquisa Geológica. ${ }^{88} \mathrm{O}$ país ainda conta com um geoportal ${ }^{89}$ gerido pelo Ministério do Ambiente.

Portugal foi um dos primeiros países a operacionalizar uma IDE no mundo. A DireçãoGeral do Território (DGTerritório) controla o Sistema Nacional de Informação Geográfica (SNIG), disponibilizado na internet desde 1995, no sentido de disponibilizar um conjunto de tecnologias, políticas e acordos institucionais que facilitam a disponibilização e acesso a informação de natureza espacial. Em 2004, foi criado o Instituto Geográfico Português, ${ }^{90}$ produtor de dados que tem a responsabilidade de gerenciar o SNIG. Há ainda um estruturado arcabouço jurídico que confere legitimidade para se empregar a infraestrutura de dados espaciais como base da gestão territorial, ${ }^{91}$ inclusive com base em softwares abertos. ${ }^{92}$

Existe pouca clareza sobre como ficará a legislação geoespacial do Reino Unido após o Brexit e, por conseguinte, sua saída do sistema INSPIRE. Todavia, pode-se afirmar que a agência de mapeamento nacional (Ordnance Survey), criada em $1746,{ }^{93}$ considerada um dos maiores produtores mundiais de mapas, continuará a ser a grande referência para o ordenamento territorial britânico. Em que pese País de Gales, Inglaterra, Irlanda do Norte e a Escócia ${ }^{94}$ terem

\footnotetext{
${ }^{87}$ Vide Decreto de 12 de janeiro de 2016.

${ }^{88}$ Referimos ao Istituto Geografico Militare; ao Istituto Idrografico della Marina; ao Centro Informazioni Geotopografiche Aeronautiche - CIGA; a Agenzia delle Entrate - Direzione Centrale Catasto e Cartografia; e ao ISPRA - Servizio Geologico.

${ }^{89}$ Ver em <www.pcn.minambiente.it/geoportal/>.

${ }^{90}$ Ver em <www.igeo.pt>.

${ }^{91}$ Vide o Decreto-Lei n. ${ }^{\circ}$ 180/2009, de 7 de agosto, que aprova o regime do Sistema Nacional de Informação Geográfica (SNIG); a Lei de Bases da Política do Ordenamento do Território e do Urbanismo (Lei n.. 31/2014, de 30 de maio); o Regime Jurídico dos Instrumentos de Gestão Territorial (Decreto-Lei nº. 380/1999 e Decreto-Lei $n^{\circ}$. 80/2015), que dentre outras coisas fixa que o plano diretor municipal deve estabelecer a referenciação espacial dos usos e das atividades, nomeadamente através da definição das classes e das categorias de espaços (art. 96. ${ }^{\circ}, 1$, "d"); os Decretos Regulamentares n. 9, $1^{\circ}$ e 11 , todos de 2011, que regulamentam o Regime Jurídico dos Instrumentos de Gestão Territorial, bem como o Decreto-Lei n. 2/2011, que cria o SIMPLEGIS e altera o local de publicação dos elementos gráficos dos instrumentos de gestão territorial. Destacam-se, ainda, a Diretiva Continente ETRS89 (PTM06) - Arquipélago dos Açores e a ITRF93 (International Terrestrial Reference Frame 1993 - Arquipélago da Madeira, como sistemas de georreferenciação oficiais empregados em Portugal.

${ }^{92}$ José Gomes dos SANTOS, <<Jangada de SIG na administração pública portuguesa〉>, Trabalho apresentado em I Jornadas Lusófonas de Ciências e Tecnologias de Informação Geográfica, In Actas das I Jornadas Lusófonas de Ciências e Tecnologias de Informação Geográfica, Coimbra, 2014, pp 554 e ss.

${ }^{93}$ Se tomarmos como referência a revolta jacobita, que foi derrotada por forças leais ao governo na batalha de Culloden em 1746. Príncipe William, Duque de Cumberland percebeu que o exército britânico não teve um bom mapa das montanhas escocesas para localizar jacobitas dissidentes, tendo posteriormente produzido mapa com escala de 1:36.000, que ficaria conhecido como "Mapa do Cumberland". Ver em <www.ordnancesurvey.co.uk>. ${ }^{94}$ Que chegou a cunhar a expressão "Uma Escócia, uma Geografia" para fomentar a integração de seus dados geoespaciais.
} 
certo nível de autonomia na produção de suas respectivas infraestruturas espaciais, o Ordnance Survey é um componente-chave da infraestrutura nacional, por possibilitar a construção de uma única base georreferenciada, o OS MasterMap, um banco de dados geográfico compatível com padrões web é considerado referência global..$^{95}$

A Rússia, territorialmente o maior país do mundo, é superlativa em diversos aspectos. ${ }^{96}$ O Serviço Federal de Registro, Cadastro e Cartografia é o órgão que sistematiza a informação de nível federal para coleta, publicação, busca, visualização e transferência de metadados espaciais de 83 órgãos governamentais diferentes e 23 mil autoridades locais, incluindo serviços web. O nível de maturidade institucional russa respalda-se em padrões abertos internacionais, atendendo a maioria dos requisitos do INSPIRE mesmo sem ser obrigatório. Seus mapas topográficos cobrem todo o território nacional com escalas que variam entre 1:10.000 e 1:100.000, com ampla base cadastral. ${ }^{97}$

Com estes exemplos europeus, fica evidenciado que, no que concerne ao ordenamento territorial, o continente consegue dar respostas satisfatórias na obtenção de geoinformação sobre seus dados naturais e humanos, em que pese muitas vezes desiguais, com atividades concentradas mais em uns países do que em outros. Com uma cultura intensa, pode-se afirmar que o tempo se expande em um espaço comprimido. Situação diametralmente oposta do continente americano, onde a cultura atualmente vigente é mais recente e precisa lidar com a ocupação de um território significativamente maior. Ou seja, o espaço se expande e o tempo se comprime.

\section{IDE na América}

O continente americano, ou as Américas, localiza-se no hemisfério ocidental e tem a maior extensão longitudinal do planeta, com em torno de 15 mil quilômetros entre os círculos polares, tendo o Oceano Pacífico a oeste e o Atlântico a leste. Tem uma área de 42.189. 120 km² com uma população de mais de 900 milhões de habitantes distribuídos em 35 países. ${ }^{98}$ Deste total, apenas 24 são membros do Comitê Permanente de Infraestrutura de Dados Geoespaciais

\footnotetext{
95 Ver em <www.ordnancesurvey.co.uk/business-and-government/products/mastermap-products.html>.

${ }^{96}$ Com 17 milhões de $\mathrm{km}^{2}$, 460 mil pontos geodésicos, 1,5 petabytes de dados geoespaciais geridos por um setor com 100 mil empregados, o país coordena um sistema de posicionamento global próprio, o Glonass.

${ }^{97}$ Referimos ao Pocpeecmpe (em inglês, Rosreestr) em <www.rosreestr.ru>.

${ }^{98}$ Dados notórios disponibilizados em <www.worldatlas.com>.
} 
(PC-IDEA). ${ }^{99}$ É considerado o continente que criou o conceito de IDE, ${ }^{100}$ sendo que os Estados Unidos foi o primeiro país a adotá-lo como tal, ${ }^{101}$ quando estabeleceu em 1994 sua IDE. ${ }^{102}$ Assim como na Europa, o desenvolvimento da IDE no continente não é uniforme, observando diversos tipos de modelos institucionais e de implementação.

$\mathrm{Na}$ Argentina, sétimo país mais extenso do mundo, com baixa densidade populacional e altamente concentrada na região metropolitana de Buenos Aires, com pretensões territoriais na Antártida e na questão Malvinas/Falkland, ${ }^{103}$ foi criada uma IDE sem personalidade jurídica, sendo que sua coordenação executiva está a cargo do Instituto Geográfico Nacional (IGN) $)^{104}$ desde 2010. Em que pese não haver uma legislação federal sobre o tema, há ao menos quatro iniciativas setoriais ${ }^{105}$ e onze províncias tem regulamentado a matéria desde $2005 .{ }^{106}$

\footnotetext{
${ }^{99}$ Referimos ao Permanent Committee For Geospatial Data Infrastructure Of The Americasespanhol, em que fazem parte, em ordem alfabética, Argentina; Belize; Bolívia; Brasil; Canadá; Chile; Colômbia; Costa Rica; Cuba; El Salvador; Equador; Estados Unidos; Guatemala; Guiana; Honduras; Jamaica; México; Nicarágua; Panamá; Paraguai; Peru; República Dominicana; Uruguai; e Venezuela.

${ }^{100}$ Atribuído ao canadense John MCLAUGHLIN (Towards National Spatial Data Infrastructure. Proceedings of the 1991 Canadian Conference on GIS, Ottawa, Canada, 1-5. Ottawa: Canadian Institute of Geomatics, 1991).

101 Vide Executive Order 12906, que criou a National Spatial Data Infrastructure (NSDI). Ver em <www.fgdc.gov/nsdi>.

${ }^{102}$ Milo ROBINSON, A History of Spatial Data Coordination. Federal Geographic Data Committee Reports and Presentations, maio de 2008.

${ }^{103}$ Este tema inclusive fomentou, em 1994, grandes discussões interdisciplinares entre Geografia e Direito por um conjunto de autores argentinos (p. ex., Juan Carlos BELTRAMINO, Jornadas sobre derecho y geografía: rationale de la relación interdisciplinaria derecho-geografía; Patricio H. RANDLE, Derecho, geografía urbana y urbanismo; e Raúl REY BALMACEDA, La región geográfica frente al derecho, sendo os três artigos constantes da Biblioteca de La Facultad de Derecho y Cs. Sociales, 341.2 J 36273. Argentina: Manantial, 1994), que estudaram inclusive a disputa pelas Malvinas/Falkland e demais temas de ordenamento territorial, demonstrando os benefícios que tal estudo traria para a ordem individual e social naquele país, no sentido de sensibilizar os profissionais que estão envolvidos com as tarefas de governo e da administração pública, os políticos, empresários, organizações não governamentais e cidadãos em geral.

${ }^{104}$ Órgão originalmente criado como Oficina Topográfica Militar, em 05 de dezembro de 1879.

${ }^{105}$ IDE Ambiente (Resolução n. 67/2015); IDE Ministério de Defesa (Resolução n. 447/13); IDE Subsecretaria de Planejamento Territorial (Disposição n. 1-E/2017) e o Observatório Nacional de Transporte do Ministério do Interior e do Transporte (Resolução n. 792/14).

${ }^{106}$ Em ordem alfabética, Buenos Aires (Decreto n. 338/2014); Catamarca (Decreto n. 248/05); Córdoba (Decreto n. 1075/2013); Chaco (Decreto n. 1565/08); Formosa (Lei Provincial n. 1.539 - Modificações da Lei n. 1.315); Jujuy (Decreto Acordo n. 1048/2012); Mendoza (Decreto n. 276/2015); Rio Negro (Decreto n. 1839/13 e sua retificação n. 1846/13); San Luís (Decreto n. 7372/12); Santa Cruz (Decreto do Poder Executivo n. 3449/07); e Santa Fé (Decreto n. 1680/05).
} 
Imagem 6

Mapa do Brasil com cartografia de 1:100.000

\section{BRASIL \\ REGIONALIZAÇÃO E ATRIBUIÇÃO INSTITUCIONAL DA CARTOGRAFIA OFICIAL - ESCALA 1:100.000 CONFIGURAÇÃO ESPACIAL 2019}

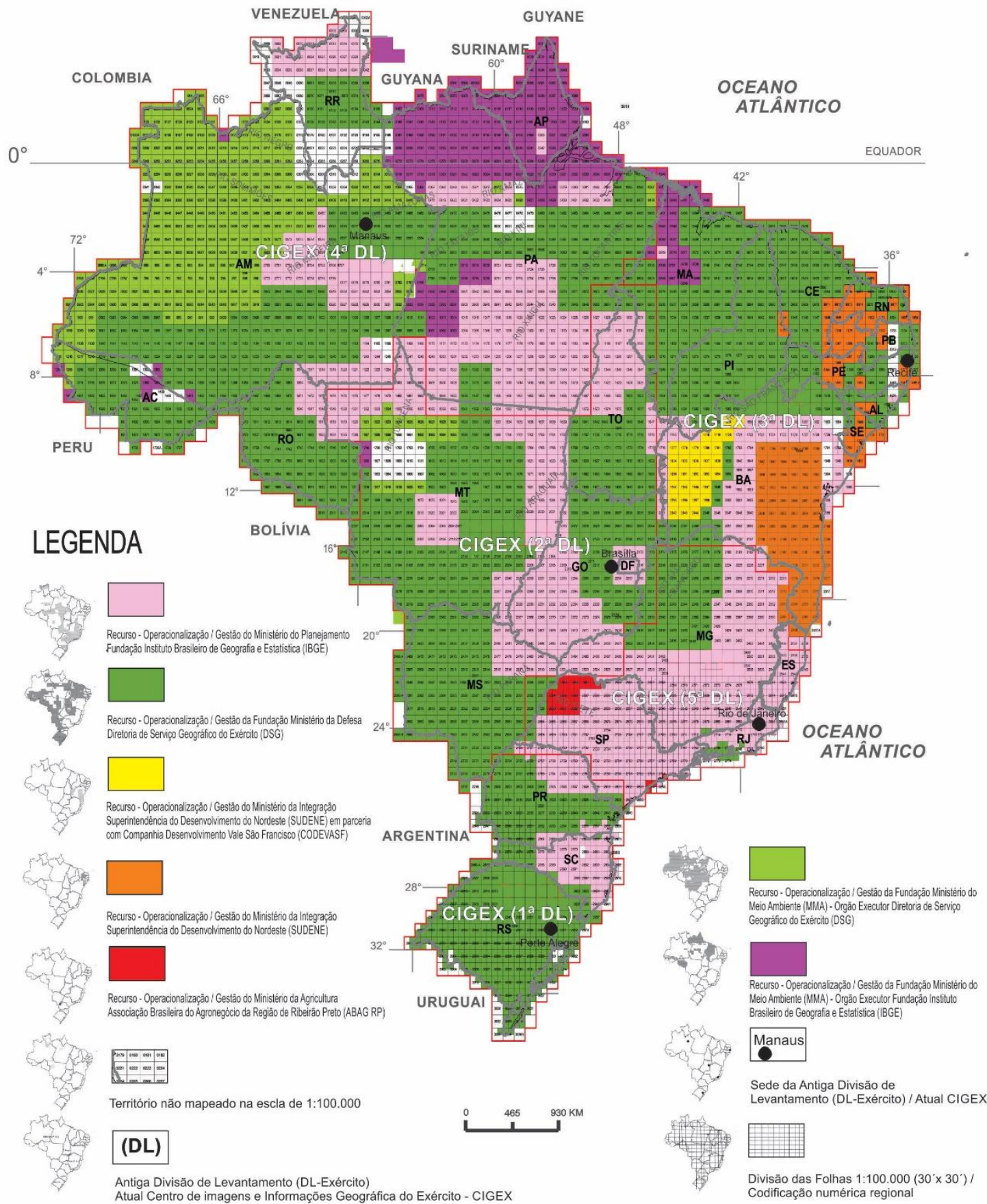

PRCJJTO GEOGRÁFICO E CARTOGRÁFICO BY PROF. DR. RAFAEL SANZIO ARAÚJO DOA ANJOS - CREA 15604/D / DR. LUIZ ANTONIO MANO UGEDA SANCHES AUXILIAR TECNICO: MATHEUS PEREIRANUNES I GUSTAVO TOLENTINO. CIGA - GEA - UNB. BRASILIA - DF. 2018 E-MAIL: cartografia@unb.br SITE: wWW.ciga.unb.br FONTE: Orgão: SEl - http://www.sei.ba.gov.br/site/geoambientais/mapas/pdf/mapa_mapaindice_2000.pdf Orgäo: SUDENE - http://wWw.sudene.gov.br/conteudo/download/mapa1.jpg / http://www.sudene.gov.br/conteudo/download/mapa2.jpg / http://www.sudene.gov.br/conteudo/download/mapa3.jpg / http://www.sudene.gov.br/conteudo/download/mapa4.jpg / Orgão: Embrapa - http://www.abagrp.cnpm.embrapa.br/material/cartografia.htm / Programa Amazonia Legal - Ministério do Meio Ambiente MMA http://www.mma.gov.br/component//2/item/8719-projeto-base-cartogr\%C3\%A1fica | Pesquisa fechada em fevereiro | 2019 
Considerando que a necessidade de se ter uma Geografia e uma Cartografia oficial é um tema constitucionalizado no Brasil, ${ }^{107}$ jamais regulamentado, ${ }^{108}$ foi instituído, no âmbito do Poder Executivo Federal, a Infraestrutura Nacional de Dados Espaciais (INDE). ${ }^{109}$ Ela serve de coordenação entre órgãos de 27 estados e mais de 5.570 municípios no quinto mais extenso país do mundo, promovendo a geração, o armazenamento, o acesso e o compartilhamento dos dados geoespaciais. O país fixa políticas públicas geográficas sem um senso de sistema, situação que pode ser notada pela ausência de cartografia nacional que cubra todo o território nacional sequer em 1:100.000, com lacunas principalmente na fronteira amazônica, ocasionando severos problemas de soberania.

De forma oposta, suas duas metrópoles (São Paulo e Rio de Janeiro) são amplamente cartografadas, mas sem que haja um único mapa oficial. Por força de sobreposição de títulos, nos cartórios o Brasil é $600.000 \mathrm{~km}^{2}$ maior do que na realidade, situação que produz insegurança jurídica na aferição de direitos e deveres. ${ }^{110}$ O Serviço Florestal Brasileiro, em dezembro de 2018, comprovou que as políticas públicas voltadas para a cartografia e a geografia não conseguem suprir, com os mecanismos atuais, diminuir a sobreposição cadastral.

No hemisfério norte, a política pública geográfica ocupa centralidade no Canadá. É o segundo maior país do mundo em área, com quase 10 milhões de $\mathrm{km}^{2}$, complexa geologia e topografia, tendo o maior litoral do mundo aliado à baixa densidade demográfica e população altamente concentrada em uma faixa de $200 \mathrm{~km}$ na fronteira com os Estados Unidos. Em consonância ao pioneirismo acadêmico de John McLaughlin ${ }^{111}$ sobre o tema, houve uma opção clara de não se desenvolver legislação federal que obrigue o país a desenvolver uma IDE. Sua governança é baseada em uma abordagem cooperativa entre os governos federais, provinciais e territoriais, indústria, academia e o público em geral. O centro canadense de observação de mapeamento da Terra, ${ }^{112}$ ligado ao departamento de recursos naturais, ${ }^{113}$ cumpre a função de

\footnotetext{
107 Vide Constituição Federal de 1988, art. 21, inciso XV.

${ }^{108}$ Luiz UGEDA, Direito Administrativo Geográfico..., pp. 377.

${ }^{109}$ Vide Decreto n. 6.666, de 3 de dezembro de 2008.

${ }^{110} \mathrm{Se}$ for considerada a área de todos os imóveis rurais cadastrados no Instituto Nacional de Colonização e Reforma (Incra), com base em informações geográficas privadas, o resultado final chega a 9,1 milhões de $\mathrm{km}^{2}$. Considerando que o Brasil tem aproximadamente 8,5 milhões de $\mathrm{km}^{2}$, esta diferença equivale a duas vezes o território do Estado de São Paulo (Roldão ARRUDA, No papel, Brasil é dois Estados de SP maior do que o oficial. Reportagem do jornal O Estado de S. Paulo em 2 de fevereiro de 2013) ou a uma península ibérica inteira. Em 2013, Ladário, município no estado do Mato Grosso do Sul, fronteiriço a Bolívia, tinha nos cartórios 397.999 hectares, mais de dez vezes do que a área real, de 34.250 hectares.

${ }^{111}$ John MCLAUGHLIN, Towards National Spatial Data Infrastructure..., pp. 4-5.

${ }^{112}$ Referimos ao Canada Centre for Mapping and Earth Observation (CCMEO) em <www.nrcan.gc.ca/>.

${ }^{113}$ Referimos ao Natural Resources Canada (NRCan) em <www.nrcan.gc.ca/>.
} 
mapeamento, de maneira que os compromissos do Canadá sob o plano de ação de governo aberto, e a respectiva abordagem colaborativa, é realizada pela infraestrutura de dados geoespaciais canadense. ${ }^{114}$

Tabela 6

Sobrecadastramento existente no Cadastro Ambiental Rural (CAR), dezembro de 2018

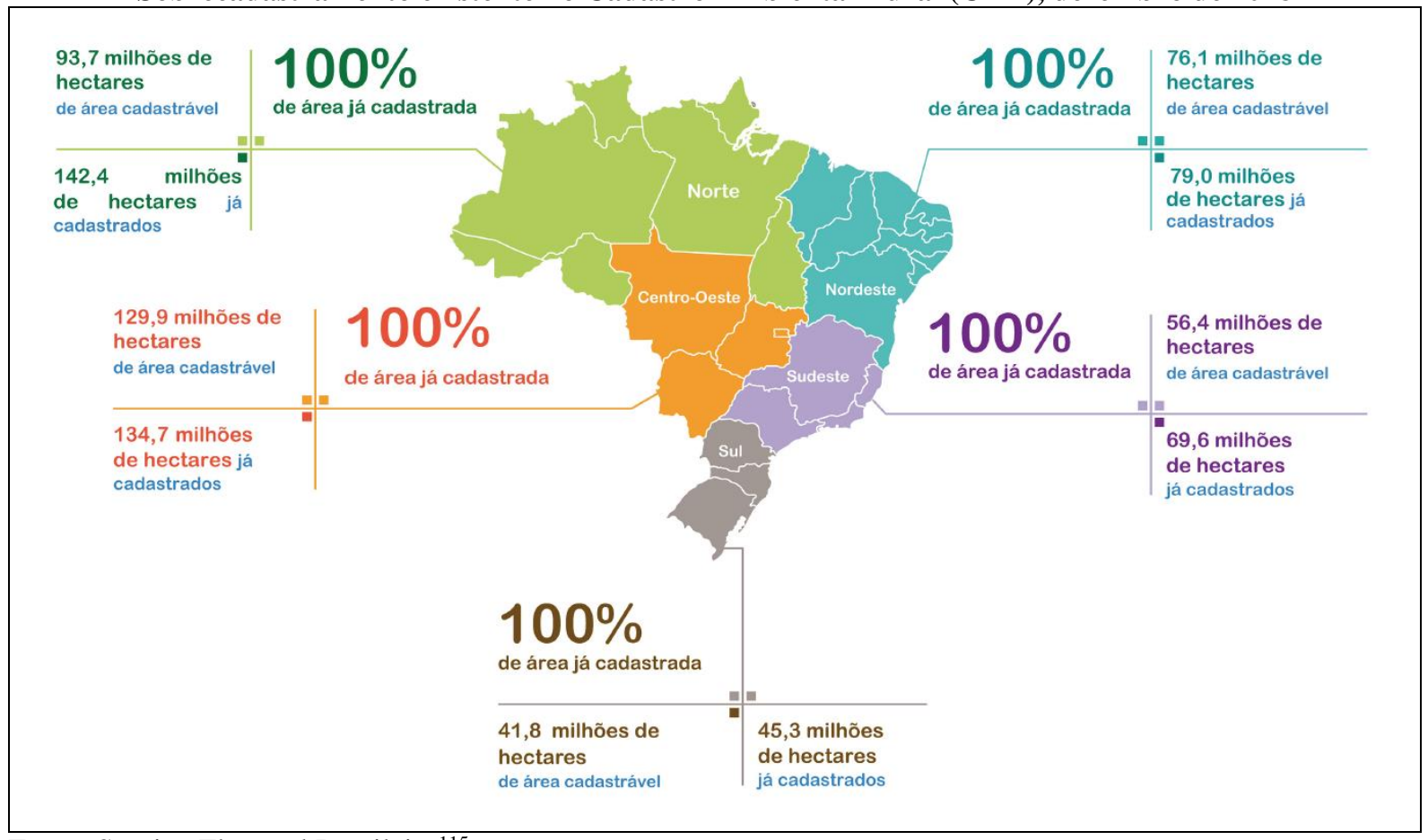

Fonte: Serviço Florestal Brasileiro ${ }^{115}$

A Colômbia tem uma relação bem definida em relação às políticas públicas geográficas. O Instituto Geográfico Agustín Codazzi (IGAC) recebeu em 1991 mandato constitucional para elaborar e atualizar o mapa oficial da República; desenvolver políticas; e implementar planos de governo nacional no campo da cartografia, agronomia, cadastro e geografia, por meio da produção, análise e divulgação de informações de cadastro e ambiental georreferenciados, a fim de apoiar os processos de planejamento e terras de uso. ${ }^{116}$ É um país andino, com diversos problemas de fronteira e de atos de guerrilha, em que a interdisciplinaridade entre Geografia e Direito tem sido explorada nessas frentes. ${ }^{117}$

\footnotetext{
${ }^{114}$ Referimos ao Canadian Geospatial Data Infrastructure (CGDI) em <www.nrcan.gc.ca/>.

115 Vide em <http://www.florestal.gov.br/documentos/car/boletim-do-car/4021-boletim-informativo-dezembrode-2018/file>

${ }^{116}$ Gustavo MONTAÑEZ GÓMEZ, Elementos de historiografía de la Geografía colombiana. Revista de Estudios Sociales, Bogotá, № 3, 1999, pp. 16.

117 María Victoria CASTRO (Derecho, espacio y poder. Aproximación a la geografia legal desde el análisis distributivo. Tesis de Doctorado en Derecho en proceso de evaluación, Universidad de Los Andes: Bogotá, 2015) chamou de "Geografia legal" o resultado das relações entre Direito, espaço e poder na Colômbia.
} 
De forma pioneira, os Estados Unidos da América (EUA), que descortinaram ao mundo as possibilidades da observação geoespacial, tem como referência a infraestrutura espacial, criada em 1994, ${ }^{118}$ vinculada a um Comitê Federal de Informação Geográfica (FGDC) que a regula, concebido em 1990. ${ }^{119}$ Esse sistema é coordenado pelo órgão de pesquisa geológica, ${ }^{120}$ que atua como agência de mapeamento civil, possuindo um Programa de Mapeamento Nacional voltado a produção de dados cartográficos básicos. Em 2008, foi instituído o Comitê Nacional Geoespacial Consultivo ${ }^{121}$ como um meio para melhorar a coordenação e governança das atividades nacionais geoespaciais, fornecendo ao FGDC um fórum para disseminar conhecimentos dentre a comunidade científica. Esta estrutura é primordial para viabilizar um relacionamento interadministrativo, produzindo cada vez mais mapas em escala grande para servir de planejamento para momentos de crise, como quando ocorre com os desastres naturais. Tem-se buscado produzir mapeamentos cada vez melhor, mais rápido e mais barato sob o notório mote "cobrá-lo uma única vez, usá-lo muitas vezes".

A Jamaica tem se destacado entre os países do Caribe, uma vez que criou, em 1991, o Conselho de Informações Territoriais (LICJ) ${ }^{122}$ para coordenar o desenvolvimento de Sistemas de Informação Geográfica (SIG) e para criar políticas e normas nacionais para o uso e acesso de dados geoespaciais. Desde então, mais de 35 entidades governamentais e empresas de serviços públicos têm utilizado SIG para apoiar suas operações. A Agência Nacional de Terras é a principal usuária, pois mantém um cadastro digital da ilha, aliada a atualização e disponibilização das 20 folhas da série de mapas topográfico de 1:50.000. ${ }^{123}$

Com base em previsão constitucional, ${ }^{124}$ o México criou a Lei do Sistema Nacional de Informação Estatística e Geográfica (LSNIEG), ${ }^{125}$ de maneira a regular e coordenar o sistema nacional de informação estatística e geográfica. ${ }^{126}$ Esta tarefa foi atribuída ao Instituto Nacional de Estatística e Geografia (INEG), criado inicialmente em 1983, mas que recebeu atribuições autárquicas para poder adquirir autonomia técnica e gerencial. Como é regra na América Latina,

\footnotetext{
118 Referimos ao National Spatial Data Infrastructure (NSDI), instituída pela Executive Order 12906, em $<$ www.fgdc.gov/nsdi/>.

119 Referimos ao Federal Geographic Data Committee (FGDC), instituída pela revisão da Lei A-16, em $<$ www.fgdc.gov/>.

${ }^{120}$ Referimos ao U.S. Geological Survey (USGS) em <www.usgs.gov>.

${ }^{121}$ Referimos ao National Geospatial Advisory Committee (NGAC) em <www.fgdc.gov/ngac〉.

122 Referimos ao Land Information Council of Jamaica (LICJ).

${ }^{123}$ Referimos ao National Land Agency (NLA) em <www.nla.gov.jm>.

${ }^{124}$ Vide artigos 26 e 73 da Constituição dos Estados Unidos Mexicanos, publicado no jornal oficial em 7 de abril de 2006.

125 A lei foi publicada em 16 de abril de 2008, tendo sido atualizada em 27 de janeiro de 2017.

${ }^{126}$ Referimos ao Sistema Nacional de Información Estadística y Geográfica (SNIEG) em <www.snieg.mx/>.
} 
o México é um país com grandes contrastes na administração das informações de cadastro e registro, apresentando deficiências na geração, no armazenamento, no tratamento, na atualização e na utilização dessas informações, com consequências no controle e organização do território, principalmente na regularização fundiária.

Com base na experiência do continente americano, pode-se perceber que a cartografia básica e a geodésia são as grandes temáticas produzidas pelas organizações nacionais de mapeamento. Pode-se afirmar, ainda, que as questões envolvendo meio ambiente, indicações geográficas, cadastro territorial e análise de ricos relacionados a desastres naturais tem sido aqueles que mais têm promovido discussões e preocupações com suas sistematizações. Vejamos agora como estes elementos se relacionam com países mais jovens e com menos recursos, como ocorre na África.

\section{IDE na África}

A África, banhada ao norte pelo mar Mediterrâneo, a leste pelo oceano Índico e pelo mar Vermelho, sendo a oeste pelo oceano Atlântico, tem cerca de $30.000 .000 \mathrm{~km} 2$ e um bilhão de pessoas, repartido entre 54 países. Continente que contém alguns dos piores indicadores sociais do mundo, tem forte influência muçulmana na região do deserto do Saara e de população nativa ao sul do deserto, com algumas áreas com forte influência europeia e, mais recentemente, asiática. ${ }^{127}$ No cenário geoespacial, a Declaração de Adis Abeba, de 2011, ${ }^{128}$ reconhece esforços regionais realizados para a gestão, a integração e a disseminação da informação geospacial no continente, implementação de políticas públicas geográficas por meio da IDE, apontando as principais iniciativas sobre o tema.

Após os acordos de paz de 2.002, que deram fim a guerra civil de Angola, houve a necessidade de reorganização do território do país. Neste contexto foi criado o Instituto Geográfico e Cadastral de Angola (IGCA), ${ }^{129}$ responsável pela gestão, regulamentação e controle da informação espacial em âmbito nacional. Embora o país tenha tido alguns progressos na produção da informação geográfica nacional, o IGCA enfrenta grandes dificuldades na implementação e coordenação da política geográfica e cartográfica nacional. O Centro Nacional de Informação Geográfica (CNIG) ainda não opera conforme idealizado. A

\footnotetext{
${ }^{127}$ Dados notórios disponibilizados em <www.worldatlas.com>.

${ }^{128}$ Gerenciamento de informações geoespaciais em direção à boa governança da terra para a Agenda 2030.

${ }^{129}$ Como órgão tutelado ao Ministério do Urbanismo e Habitação que substituiu o Instituto de Geodesia e Cartografia de Angola, tutelado ao Ministério da Defesa Nacional, por força do Decreto-Lei n. ${ }^{\circ}$ 4/03 de 9 de Maio, que aprovou o Estatuto orgânico do Ministério do Urbanismo e Ambiente.
}

Revista Eletrônica: Tempo - Técnica - Território, V.10, N.1 (2019), 01:51 ISSN: 2177-4366 
Escola de Topografia, apesar de já ter formado muitos profissionais, funciona de maneira subutilizada e com infraestrutura obsoleta. ${ }^{130}$

O Instituto Nacional de Cartografia e Sensoriamento Remoto ${ }^{131}$ da Argélia foi criado em 1967 e atualmente é classificado como um estabelecimento público sob o setor econômico do Ministério da Defesa Nacional, com competência para produzir, pesquisar, conservar e difundir a informação geográfica mantendo o sistema geodésico, a cobertura do território por fotografia aérea e uma base topográfica com mapeamento entre 1:200.000 e 1:50.000. Atualmente o INCT tem diversos clientes que representam vários sectores como a defesa, agricultura, ordenamento do território, telecomunicações, energia e cadastro, sendo a estratégia reforçada pela criação, em 2002, da Agência Argelina de Espaço (ASAL), ${ }^{132}$ facilitando a obtenção de informação geoespacial.

A estrutura nacional de mapeamento da Costa do Marfim é o Centro de Mapeamento e Sensoriamento Remoto (CCT) ${ }^{133}$ do Instituto Nacional de Estudos Técnicos e Desenvolvimento (BNETD). ${ }^{134}$ O BNETD estar sob a tutela direta da Presidência da República, ${ }^{135}$ com responsabilidade de realizar ou executar a obra geográfica de interesse geral sobre o território nacional; coordenar, padronizar e controlar o trabalho geográfico desenvolvido por terceiros, com a participação financeira do estado; e centralizar os dados geográficos realizados no país.

A Agência Central pela Mobilização Pública e Estatística (CAPMAS) ${ }^{136}$ do Egito $^{137}$ é o órgão estatístico oficial do país para coleta, processamento, análise e disseminação de informação estatística. O Departamento de Sistema de Informação Geográfica do CAPMAS é responsável por agregar aos dados estatísticos os dados geoespaciais referentes aos limites

\footnotetext{
${ }^{130}$ Dilson KITOKO, Marco PAINHO, “A informação geográfica em Angola: subsídios para a elaboração de uma estratégia e plano de ação de apoio à implementação do plano nacional de informação geográfica”. Imprensa da Universidade de Coimbra, Coimbra, 2015, 520.

${ }^{131}$ Referimos ao Institut National de Cartographie et de Télédétection (INCT) em 〈www.inct.mdn.dz〉.

132 Pelo Decreto presidencial n. 02-48, de 2002.

${ }^{133}$ Referimos a Centre de Cartographie et de Télédétection (CCT). Criado em 20 de julho de 1992, nos termos do Decreto n. ${ }^{\circ}$ 92-86 em 17 de fevereiro de 1992, com a fusão por absorção de estabelecimentos públicos de mapeamento e de controle de obras.

${ }^{134}$ Referimos a Bureau National d'Etudes Techniques et de Développement (BNETD) em <www.bnetd.ci>.

135 Kouadio KONAN, Réseau Géodésique de Côte d'Ivoire (RGCI). Document de vulgarisation publié par BNETD/CCT, 2ème édition, Abidjan, novembre 2006, pp. 5.

136 Referimos ao Central Agency for Public Mobilization and Statistics (CAPMAS), conforme Decreto Presidencial $n^{\circ} 2915$, de 1964.

${ }^{137}$ A República Árabe do Egito está situada no nordeste da África e na península do Sinai, que se localiza no sudoeste asiático. É por isso que o Egito também é chamado um país do Oriente Médio, sendo o terceiro país mais populoso da África e o mais populoso no Médio-Oriente com a maioria de sua cerca de 90 milhões pessoas vivendo sobre ou próximo, às margens do Rio Nilo. Apenas 5,5\% da área total da terra é utilizado pela população, às margens do rio Nilo e em alguns oásis, sendo os demais 94,5\% considerados deserto inabitável.
} 
administrativos. A regulação do país ainda é bastante frágil e necessita de contundentes aperfeiçoamentos para lidar com o impacto que a grande natalidade terá no ordenamento territorial do país.

Em Moçambique, país que teve o primeiro censo da história contemporânea africana, ${ }^{138}$ tem uma rica história relacionada ao ordenamento territorial com base em políticas públicas geográficas. Em 2002 foi criado o Centro Nacional de Cartografia e Teledetecção (CENACARTA) como uma instituição autônoma, subordinada ao Ministério da Agricultura, com a responsabilidade de coordenar todas as atividades de sensoriamento remoto em nível nacional, sendo a autoridade responsável pela produção de informação geográfica de base, com vista a assegurar o desenvolvimento sustentável do país. Todavia, a legislação do país é considerada incompleta, com falta de padronização cartográfica, insuficiência de pessoal, de fundos e a ausência de um Conselho Nacional de Cartografia que possa conferir um planejamento estratégico para as atividades da CENACARTA. ${ }^{139}$

A Nigéria demonstra um cenário peculiar em relação à geoinformação. É o país mais populoso e rico da África, em que pese ter um PIB per capita baixo, e se encontra em franco crescimento populacional ${ }^{140}$ em momento de crise do petróleo, seu principal produto. Muitas das questões limitando as oportunidades de investimento na Nigéria poderiam ser resolvidas pelo agrupamento, compartilhamento e utilização de dados geográficos e demográficos. Todavia, o Estado tem-se demonstrado desinteressado por este tipo de solução. Em que pese ter um avançado sistema de observação via satélite, ${ }^{141}$ o desenvolvimento de sistemas de informação geográfica estão a cargo dos estados da federação. ${ }^{142} \mathrm{O}$ Geoportal é considerado muito aquém das possibilidades do país, ${ }^{143}$ que continua a buscar soluções para seus mais de $4 \mathrm{mil} \mathrm{km}^{2}$ de fronteiras e da necessidade de se ter um controle mínimo do ordenamento territorial e dos registros de propriedades. ${ }^{144}$

\footnotetext{
${ }^{138}$ Em África o primeiro censo foi realizado em Moçambique em 1928, enquanto território português. Só na década de 40 foram realizados censos no Botswana, África do Sul, Suazilândia e na Tunísia.

${ }^{139}$ Raúl Afonso CUMBE, Andrea Flávia Tenório CARNEIRO, Um estudo para o aperfeiçoamento da cartografia sistemática de Moçambique com base na experiência brasileira. V Simpósio Brasileiro de Ciências Geodésicas e Tecnologias da Geoinformação. Recife, 12-14 de novembro de 2014, pp. 92.

${ }^{140}$ Estimativas do Departamento de Recenseamento dos Estados Unidos apontam que a população da Nigéria irá atingir 602 milhões em 2100, sendo o terceiro país mais populoso do mundo.

${ }^{141}$ Nigéria lançou três satélites de observação (EO) de terra - NigeriaSat-1 (32m de resolução espacial), em 2003 e NigeriaSat-X (resolução de 22m) e NigeriaSat-2 (2,5 m PAN e 5m MX) em 2011 - bem como um satélite de comunicação (NigComSat-1R).

${ }^{142}$ Olivia KOLBE-BOOYSEN, The Challenges of Using Spatial and Demographic Data for Development in Nigeria. 2017 World Bank Conference on Land and Poverty, The World Bank - Washington DC, March 20-24, 2017 pp. 9 e ss.

${ }^{143}$ Vide em <www.ngdi.gov.ng>.

144 Adewale ADEGOKE, Standards and Interoperability in the Nigerian Land Sector. 2017 World Bank Conference on Land and Poverty, The World Bank - Washington DC, Março, 20-24 de 2017, pp. 12.
} 
A infraestrutura de dados espaciais da África do Sul (SASDI) ${ }^{145}$ é uma iniciativa governamental para desenvolver normas técnicas sobre a utilização de dados geográficos, tais como mapas, imagens aéreas e por satélite. Também procura facilitar a captura, gerenciamento, manutenção, integração, distribuição e utilização de informação espacial na África do Sul. A Lei de Infraestrutura de Dados Espaciais ${ }^{146}$ possibilitou a promoção do uso eficiente e eficaz dos recursos de informação geográfica do estado pelo compartilhamento das informações. É considerado um direito constitucional de acesso à informação, cabendo ao Estado disponibilizar dados necessários para o exercício ou proteção de direitos.

A IDE na África pode ser considerada como a menos desenvolvida do mundo, e em princípio não demonstra uma correlação entre poder econômico e o desenvolvimento da IDE. Os temas mais destacados são as questões cadastrais e, mesmo detendo alguns dos satélites mais modernos do mundo, as políticas públicas não estão voltadas para a observação espacial. Em que pese haver agências ou institutos que promovem o mapeamento, são raros os casos em que há uma política pública geográfica sendo conduzida por um conselho, situação que compromete a qualidade da governança setorial.

\section{IDE na Ásia e Oceania}

O continente asiático é o maior do planeta, tanto no que concerne ao território quanto referente à população, contendo um terço da superfície e três quintos da população. Compreendida entre a linha do Equador e o círculo polar ártico, tem alguns dos indicadores mais significativos do planeta. Por exemplo, tem a montanha mais alta do mundo, o monte Everest, a altitude máxima do planeta, localizada a 8.848 metros acima do nível do mar, bem como a maior depressão, o litoral do mar Morto, localizada a 396 metros abaixo do nível do mar, entre Israel e a Jordânia. ${ }^{147}$

No que concerne aos temas geoespaciais, a China, sendo o país mais populoso do mundo e com a terceira maior extensão territorial, tem uma legislação consolidada e de fácil acesso sobre o tema. A Administração Nacional de Agrimensura, Mapeamento e Geoinformação (NASG), ${ }^{148}$ sob gestão do Ministério da Terra e dos Recursos Naturais do Conselho de Estado,

\footnotetext{
${ }^{145}$ Referimos ao South African Spatial Data Infrastructure (SASDI) em <www.sasdi.gov.za>.

146 Lei n. 54, de 2003.

${ }^{147}$ Dados notórios disponibilizados em <www.worldatlas.com>.

148 Referimos ao 国家测绘地理信息局 (em inglês, National Administration of Surveying, Mapping and Geoinformation - NASG) em <nasg.gov.cn>.
}

Revista Eletrônica: Tempo - Técnica - Território, V.10, N.1 (2019), 01:51 ISSN: 2177-4366 
é a autoridade central responsável pela total supervisão e gestão de agrimensura, geoinformação e mapeamento de trabalho do país. ${ }^{149}$

As Filipinas têm um órgão de mapeamento nacional, concebido em forma de agência. ${ }^{150}$ Ela fornece serviços de cartografia, servindo de repositório para distribuição de mapas, cartas náuticas e outros dados públicos. Suas funções principais são disponibilizar base topográfica, mapeamento, desenvolvimento da rede geodésica nacional, classificação de terras, levantamentos hidrográficos, delimitação de fronteiras marítimas e gestão de informação geográfica. ${ }^{151}$

A Índia, em vias de se transformar no país mais populoso do mundo nas próximas duas décadas, tem uma longa tradição em coletar sistematicamente dados espaciais por meio de várias organizações nacionais, ${ }^{152}$ tendo dotado o país de uma base ampla e poderosa. ${ }^{153}$ Iniciativas mais recentes do governo buscam tornar obrigatória a permissão de uma autoridade do governo antes de adquirir, divulgar, publicar ou distribuir qualquer geoinformação da Índia, situação que criou problemas com a iniciativa privada ${ }^{154}$ e com o Paquistão. ${ }^{155}$ Do outro lado da península, questões sobre enclaves são frequentes. ${ }^{156}$ Os 102 enclaves existentes entre a Índia

\footnotetext{
149 A NASG consiste em um conjunto de mais de vinte instituições e tem uma equipe total superior a 6.200 funcionários distribuídos entre os níveis centrais, provinciais, municipais e os condados. No nível provincial, $68 \%$ da topografia, do mapeamento e da geoinformação são independentes, enquanto os $32 \%$ restantes são públicos, sendo $14 \%$ pertencentes aos departamentos de planejamento urbanos. No que concerne à legislação, existem quatro regulamentos administrativos, 35 regulamentações locais, seis regras departamentais e 74 regras governamentais locais no quadro jurídico da China. Os quatro regulamentos administrativos dispõem sobre a compilação do mapa público, sobre agrimensura e gerenciamento de resultados de mapeamento e disposições básicas de topografia e mapeamento.

${ }^{150}$ Referimos a National Mapping and Resouce Information Autority (NAMRIA) em <www.namria.gov.ph>.

151 Os produtos NAMRIA são disponibilizados na forma analógica e digital, incluindo mapas topográficos (1:250.000, 01:50.000; 1:10.000 e maiores), mapas administrativos, cartas náuticas, mapas de navegação eletrônicos e mapas de cobertura florestal/terra. Para a escala de 1:250.000, existem 55 folhas de mapa digital, cobrindo toda área e 675 mapas para 1:50.000 com folhas de 165 mapas atualizados.

152 Pramod K. SINGH, Governance Issues in GIS Infrastructure in India. International Journal of Rural Management, 1(2) : 223-244. 2005 pp. 223 e ss.

${ }^{153}$ Indian Space Research Organisation - ISRO, National Spatial Data Infrastructure: Strategy and Action Plan. Discussion Document. ISRONNRMS-SP-75-2001, Bangalore, 2001.

${ }^{154} \mathrm{O}$ órgão regulador passaria a conceder licenças para pessoas físicas e jurídicas que desejarem usar dados geoespaciais, verificando previamente o conteúdo e os dados fornecidos, e certificando se estão dentro das políticas nacionais, com o objetivo de proteger a integridade, a soberania e a segurança nacional. Caso aprovada, será uma medida de impacto direto em empresas como o Google, Uber, Zomato, AirBnB, Twitter e Facebook, que podem rastrear a localização com base na computação ubíqua. A aquisição ilegal de informações geoespaciais da Índia passaria a acarretar desde multa até prisão por um período máximo de sete anos.

155 O Paquistão, país com diversos conflitos territoriais com a Índia, chegou a afirmar que os mapas públicos indianos violam resoluções da ONU, pois retratam os territórios de Jammu e da Caxemira como parte da Índia, o que seria juridicamente insustentável e factualmente incorreto.

${ }^{156}$ Para aprofundamento do tema, ver Evgeny VINOKUROV, A Theory of Enclaves. Lexington Books. 2007.
}

Revista Eletrônica: Tempo - Técnica - Território, V.10, N.1 (2019), 01:51 ISSN: 2177-4366 
e Bangladesh, necessitam de mapas e de normas para regular a fronteira que é considerada como o mais complexa do mundo, ${ }^{157}$ em que residem mais de 50 mil pessoas. ${ }^{158}$

No Estado de Israel há a Agência Central de Estatística (ICBS), que opera diretamente sob o escritório do primeiro-ministro e é responsável pela criação e manutenção de dados geoestatística. O ICBS atribui código individualizado a cada logradouro público em Israel, sendo reconhecido por todas as entidades governamentais e particulares. O registro de população israelense é geocodificado e toda a população está dividida espacialmente para efeitos de sufrágio eleitoral. Essa metodologia foi implementada, pela primeira vez, pelo censo de 2008, que integrou dados de fontes administrativas, juntamente com dados amostrais. ${ }^{159}$

No Japão, de centenária regulação geográfica, ${ }^{160}$ várias organizações são responsáveis pela topografia básica, pelo mapeamento e pela criação de projetos gráficos. Processos de base geodésica são realizados principalmente pela Autoridade de Informação Geoespacial, ${ }^{161}$ pelo Departamento Hidrográfico e Oceanográfico $(\mathrm{HOD})^{162}$ e pelo Ministério da Terra, Infraestrutura, Transportes e Turismo (MLIT). ${ }^{163}$ Com base na lei básica sobre o avanço da informação geoespacial, ${ }^{164}$ o governo determinou o plano para o avanço das informações básicas geoespaciais. Foi criado o "Japão Digital", uma representação virtual e em tempo real das várias informações geoespaciais, acessível a qualquer pessoa na internet. ${ }^{165}$

\footnotetext{
157 Os primeiros-ministros da Índia e Bangladesh assinaram o acordo de fronteira terrestre em 1974, objetivando trocar enclaves e simplificar suas fronteiras internacionais. Uma versão revisada do acordo foi adotada pelos dois países em 7 de maio de 2015, quando o Parlamento da Índia passou a $100^{\mathrm{a}}$ emenda à Constituição indiana. Este acordo foi ratificado em 6 de junho de 2015, sendo que a Índia recebeu 51 enclaves de Bangladesh (7.110 hectares), enquanto Bangladesh recebeu 111 enclaves indianos (17.160 hectares) no continente do Bangladesh.

${ }^{158}$ Dentro do território de Bangladesh existem 102 enclaves de território indiano, que por sua vez, contém 21 subenclaves de Bangladesh, um do qual contém um sub-sub-enclave indiano. Dentro do território indiano, são 71 enclaves de Bangladesh, contendo 3 sub-enclaves indianos. Um censo comum em 2010 identificou 51.549 pessoas residentes nestes enclaves: 37.334 em enclaves indianos dentro Bangladesh e 14.215 em enclaves de Bangladesh na Índia. Ver em The Economist. "Mapped out - A cartographic anomaly is resolved". Asia edition, 13 de junho de 2015.

${ }^{159}$ Referimos ao Central Bureau of Statistics (CBS) em <www.cbs.gov.il>.

${ }^{160}$ A primeira seção de registo cadastral e de mapas foi estabelecida em 1869 , no escritório do departamento de Geografia. Mais tarde, em 1888, ele foi reorganizado como levantamento de terra do império japonês, sendo transformado em 1945 no Instituto de Pesquisa Geográfica.

${ }^{161}$ Referimos ao 国土地理院の日本 (em inglês, Geospatial Information Authority of Japan - GSI), ligado ao Ministério de Terras, Infraestrutura e Transporte. Ver em 〈www.gsi.go.jp〉. Cabe ao GSI preparar os diversos mapas de base, nomeadamente o mapa topográfico de 1:25.000 que cobrem todo o país para uso de controle da terra, prevenção de desastres naturais, atividade vulcânica, gesto da área urbana, dentre outros. Estes mapas estão disponíveis em papel e em formato digital, sendo que fotografias aéreas também são publicadas.

${ }^{162}$ Ver em Hydrographic and Oceanographic Department (HOD) em <www1.kaiho.mlit.go.jp>.

163 Referimos ao 国土交通省 (em inglês, Ministry of Land, Infrastructure, Transport and Tourist) em <www.mlit.go.jp>.

${ }^{164}$ Vide Lei n. ${ }^{\circ} 63$ de 2007, implementada em agosto de 2007.

165 Conforme existente em Japan Profile for Geographic Information Standards (JPGIS), ver em <www.gsi.go.jp>.
} 
A Autoridade de Terras de Singapura (SLA) ${ }^{166}$ é o órgão responsável pela administração e gestão das propriedades, sendo o responsável pelos registros. Sendo um território pequeno, ${ }^{167}$ a SLA gerencia o intercâmbio entre os dados sobre as terras nos órgãos públicos, bem como licencia os mapas de ruas online e impressos. Também é uma agência-chave para estabelecer a infraestrutura nacional de dados espaciais, pois ela digitaliza ar autoestradas, os limites de propriedades, os contornos de habitações e os edifícios industriais, agrupando todas essas camadas em uma plataforma pública. ${ }^{168}$

Logo no início de 1900, o Sri Lanka tinha estabelecido rede de triangulação geodésica para mapear toda a ilha em razão de uma polegada a uma milha. ${ }^{169} \mathrm{Em} 2002$, nova legislação criou a Rede de Controle Geodésico Nacional ${ }^{170}$ para ordenamento territorial, ou seja, para receber, aprovar e manter registros de topografia cadastral a fim de facilitar a produção de planos de levantamento cadastral e mapas para servir como base abrangente de integração de informações sobre o terreno. ${ }^{171}$

A Turquia, ${ }^{172}$ com a Agência Nacional de Mapeamento, ligada ao Comando-Geral de Mapeamento $(\mathrm{GCM}),{ }^{173}$ é responsável pelo estabelecimento e manutenção das redes geodésicas, coleta e estruturação de dados topográficos e as informações geoespaciais, ${ }^{174}$

\footnotetext{
166 Referimos a Singapura Land Autority.

${ }^{167}$ É considerada uma cidade-Estado insular, localizada 137 quilômetros ao norte da linha do Equador, no Sudeste Asiático, na ponta sul da península malaia.

${ }^{168}$ Ver em <www.map.gov.sg>. Há um rol completo de serviços geoespaciais no portal, que incluem a posse da propriedade, histórico de transações, questões relacionadas à educação, localização de escolas e demais serviços.

${ }^{169}$ Esta série de mapa, popularmente conhecido como One Inch Maps consistem na produção de 72 folhas que cobriram toda a ilha, que corresponde a uma escala aproximada de 1:40,000. Em 1956, o Sri Lanka foi fotografado à escala de 1:40.000 por uma empresa estrangeira. Nas décadas seguintes, o país foi fotografado novamente na escala de 1:10,000 (5\% de cobertura), 1:20.000 (100\% de cobertura) e 1:40.000 (70\% de cobertura). Durante a década de 1980 com a assistência do projeto Sri Lanka/Swiss sensoriamento remoto, foram adquiridas imagens de satélite e software para atividades de levantamento de processamento de imagem. Com o desenvolvimento tecnológico, nova rede geodésica para todo o país foi criada em 1999 para trabalhar com sistemas de posicionamento global, sendo que a precisão estatística da rede atual é de cerca de 1:750.000, que é apropriado para procedimentos de levantamento cadastral e mapeamento de presente. Ver em 〈www.sdi.survey.gov.lk〉.

${ }^{170}$ Ver Lei de Pesquisa (Survey Act) n. 17, de 2002.

${ }^{171}$ Referimos ao Sri Lanka Spatial Data Infrastructure (SLSDI) em <www.sdi.survey.gov.lk>.

${ }^{172}$ A Turquia, para efeitos do presente trabalho, em que pese ser um país euro-asiático, para efeitos didáticos foi alocada como país asiático por ocupar toda a península da Anatólia, no extremo ocidental da Ásia, em que pese ter territórios na Trácia Oriental (também conhecida como Rumélia), no sudeste da Europa.

${ }^{173}$ Em turco, Harita Genel Komutanlı̆̆ (em inglês National Mapping Agency of Turkey, General Command of Mapping - GCM) em <www.hgk.msb.gov.tr>.

174 No sítio do Comando-Geral de Mapeamento, de cunho oficial e militar, há diversas informações militares. Como exemplo, afirma-se que Mustafa Kemal Atatürk, o grande líder e fundador da República da Turquia, costumava pontuar que as vitórias militares eram devidas aos gráficos e mapas desenvolvidos pelo estado. $\mathrm{O}$ mapeamento turco remonta ao século XV, quando Ibrahim Mursel pintou mapas ao almirante Piri Reis, famoso comandante da Marinha do Império Otomano. Até o final do século XIX, um grande número de mapas, gráficos ou obras similares podem ser encontrados refletindo o aspecto histórico do mapeamento turco. Considera-se como início da cartografia moderna na Turquia o estabelecimento da comissão de mapeamento em 1895, sendo criada, em 28 de outubro de 1918, departamento independente de mapeamento no ministério da defesa nacional, incluindo atividades de triangulação, topografia, reconhecimento, cartografia, escritórios centrais, um batalhão de Agrimensura e uma escola de Agrimensura. Ver em <www.hgk.msb.gov.tr〉.
}

Revista Eletrônica: Tempo - Técnica - Território, V.10, N.1 (2019), 01:51 ISSN: 2177-4366 
fornecendo informações precisas, atualizadas e módicas por meio do Ministério de Meio Ambiente e Planejamento Urbano. ${ }^{175}$ A IDE turca têm uma origem e uma destinação predominantemente militar desde a guerra de independência. Com o tempo, a Agência Nacional de Mapeamento foi além das finalidades militares e transformou o trabalho em parte integrante da vida social, com importantes responsabilidades no ordenamento territorial.

Austrália e Nova Zelândia, países da Oceania, ${ }^{176}$ compartilham o Conselho de Informação Espacial, ${ }^{177}$ organização intergovernamental que fornece gestão e utilização de informação geoespacial aos principais países da Oceania. Mesmo com diferentes necessidades, relacionadas ao registro de terras, controle de transporte e coleta de dados sobre recursos naturais e físicos, este Conselho tem emergido como o agente de melhoria da gestão de informação espacial coordenando órgãos para incentivar e promover esforços de especialistas para desenvolver políticas, normas e atividades que tem ganho, cada vez mais, aceitação generalizada.

\section{A CONSTRUÇÃo dA JUSTIÇA TERRITORIAL PELO GEODIREITO E A FUNÇÃO DA INFRAESTRUTURA DE DADOS ESPACIAIS}

Pode-se notar, com base nas informações acima, que é possível fazer um recorte da história da humanidade pelo emprego da Geografia e da cartografia enquanto política pública por meio de uma infraestrutura passível de regulação, mostrando que é alta a correlação entre nações desenvolvidas e robusta Geografia de Estado. Que a produção de censos, mapas, sistemas ou geoinformações, enquanto técnicas estatais, mais do que compreender uma realidade social para fixar uma ordem perante um território, constitui claramente um elemento central da nova arrumação da questão social em um ambiente de arena global. ${ }^{178} \mathrm{E}$ esta arena, espaço de pretensões resistidas, usa como plataforma de disputa uma espécie de "território

\footnotetext{
175 Mehmet SIMAV. "National Report of Turkey". National Mapping Agency, General Command of Mapping from Turkey. EUREF 2012 Symposium, Poland. 2012, pp. : 9.

${ }^{176}$ A Oceania, ou o Novíssimo mundo, é um continente banhado pelo Oceano Pacífico formado por três grandes conjuntos de ilhas, denominadas de Polinésia, Melanésia e Micronésia. Com exceção da Antártica, de forma oposta a Ásia, é o menor continente em área e em população, compreendendo a Austrália e as ilhas adjacentes. As peculiaridades do continente podem ser estendidas aos aspectos geoepaciais. Pode-se afirmar que os dois maiores países da região têm uma gestão compartilhada de seus dados. Dados notórios disponibilizados em <www.worldatlas.com>.

${ }^{177}$ Referimos ao Australia New Zealand Land Information Council (ANZLIC) em <www.anzlic.gov.au>.

${ }^{178}$ Suzana TAVARES DA SILVA, Direitos fundamentais na arena global, $2^{\text {a }}$ Edição. Imprensa da Universidade de Coimbra : Coimbra. 2014, pp. 171.
} 
usado", ${ }^{179}$ um espaço em permanente diálogo com os atores que dele se utilizam, sob um processo dialético no qual se incluem as coisas naturais e artificiais, a herança social e a sociedade em seu movimento atual.

Tecnologias disruptivas têm ocasionado inúmeras preocupações em relação às liberdades individuais e a alocação entre público e privado a novos patamares. Pessoas se georreferenciam voluntariamente para se relacionar em redes sociais, ${ }^{180}$ chamar táxi, ${ }^{181}$ namorar, ${ }^{182}$ entreter com realidade aumentada; ${ }^{183}$ dentre outros. A massificação do acesso à tecnologia geográfica decorrente da proliferação de smartphones viabiliza rápido acesso a diversas formas de mapas e, todos estes elementos em conjunto moldam o estilo de vida neste início de século.

Há um lado funesto nessa perspectiva tecnológica, pois existe a real possibilidade de fazer impor não apenas a completa obediência à vontade do Estado, mas também a uniformidade de opinião em todos os súditos. ${ }^{184}$ Chega-se ao ponto de se cunhar a expressão "Geoescravo" para alertar sobre invasões de privacidade em face da expansão desenfreada de serviços baseados em geolocalização, ${ }^{185}$ situação que tornaria os usuários de ferramentas de geolocalização em escravos, pois conferem de forma espontânea todos seus dados pessoais para usos múltiplos. Por outro lado, há políticas públicas para mapear tudo e qualquer coisa que tenha interesse do Estado, que georreferencia os cidadãos para efeitos tributários, ${ }^{186}$ criminais, ${ }^{187}$ gestão de detentos; ${ }^{188}$ e até de espionagem. ${ }^{189}$ Geografia e Cartografia tendem a se transformar em algoritmos, e os países no século XXI poderão ser divididos entre os que programam e os que são programados.

Sistemas mais complexos de mapeamento têm sido estudados e incentivados, como é o caso do desenvolvimento de redes inteligentes, ${ }^{190}$ prevenção de catástrofes naturais,

\footnotetext{
${ }^{179}$ Para Milton SANTOS (Território e Sociedade. $2^{\mathrm{a}}$ ed., $4^{\mathrm{a}}$ reimpressão. São Paulo: Editora Fundação Perseu Abramo, 2009 pp. 26 e ss), o espaço deve ser compreendido na perspectiva de movimento e fluidez, própria da dinâmica de conflitos da produção social, formando o território usado.

${ }^{180}$ Como exemplo, Facebook, Google+; Twitter, Instagram, dentre outras.

${ }^{181}$ Como exemplo, Uber, MyTaxi; Taxi Digital, dentre outros.

${ }^{182}$ Como exemplo, Tinder, Badoo, Happn, dentre outros.

${ }^{183}$ Como exemplo, Pokémon Go, Zombies, Run!, Parallel Kingdom, dentre outros.

${ }^{184}$ George ORWELL, 1984. 29a. Ed. São Paulo: Companhia Ed. Nacional, 2005, pp. 198.

185 Jerome DOBSON, Peter FISHER, GeoSlavery, Technology and Society Magazine, IEEE, Volume 22, 2003, pp. 47.

${ }^{186}$ Vide inserir nas notas fiscais o número de contribuinte, situação que faz com que os cidadãos permitam ao Estado conhecer seus hábitos econômicos e sociais, cruzando com demais dados que permitem obter inúmeras conclusões.

${ }^{187}$ A Polícia, com base nas informações passadas pela inscrição do número de contribuinte em cada nota fiscal, passa a ter condições privilegiadas de proceder investigações sobre elisão fiscal.

${ }^{188} \mathrm{P}$. ex., questões tecnológicas e jurídicas no que concerne o uso de GPS como tornozeleira de detentos.

189 Vide notório caso Snowden.

${ }^{190}$ No caso do setor elétrico, é possível, de forma online, identificar furtos, fraudes, inadimplências, ocupação de servidões, compartilhamento de infraestruturas, necessidade de poda de árvores, dentre inúmeras outras repercussões pelo conceito de smart grid.
}

Revista Eletrônica: Tempo - Técnica - Território, V.10, N.1 (2019), 01:51 ISSN: 2177-4366 
urbanização de favelas em países em desenvolvimento, planejamento ambiental, mapeamento de pessoas com necessidades especiais, minorias étnicas, dentre outras inúmeras funções. Rumamos a um modelo democrático regido por algoritmos, ou a "Datacracia", ${ }^{191}$ onde os estados irão, cada vez mais, coletar, analisar, reportar e executar políticas públicas com base no Big Data e na geoinformação, por meio de um conjunto de componentes como smartphones, mídias sociais, ${ }^{192}$ sensoriamento remoto (câmeras, drones, aerolevantamentos, imagens de satélites), veículos autônomos, sensores em bicicletas ou em relógios que medirão passos, velocidades, batimentos cardíacos, correlacionando, em tempo real, todos os eventos que ocorrem no interior de uma sociedade. O que vamos fazer com todo este poder? ${ }^{193}$

Como exemplo, discutir Geografia no Direito, até a década passada, impunha uma visão eminentemente sociológica ou predominantemente economicista, em que se debatia a hipótese de se abolir o controle supranacional para viabilizar a concorrência entre jurisdições em defesa do espaço geográfico nacional, ${ }^{194}$ de maneira a atrair empresas multinacionais. Neste sentido, Natalino Irti propôs o Geodireito ${ }^{195}$ enquanto resposta jurídica para regular os abusos da globalização econômica. Todavia, o que atualmente se impõe é uma necessidade de os estados controlarem o volume de informações de maneira a garantir as liberdades individuais.

O Geodireito, que tem como objeto o estudo da morfologia jurídica do território, aflora dentro deste contexto como uma resposta para atualizar as milenares políticas públicas geográficas sob este desafiador contexto. Busca compreender a dinâmica das categorias geográficas perante a arena global com base fenomenológica (fato geográfico e jurídico); axiológica (relações geográficas e jurídicas); e instrumental (o mapa, a norma e a infraestrutura de dados espaciais enquanto resultante). Esta forma tridimensional ${ }^{196}$ de compreender a

${ }^{191}$ Derrick de KERCKHOVE, <<Mobile culture in Singapore>> In Ana Serrano Tellería (Org), Between the Public and Private in Mobile Communication. Series Routledge Studies in New Media and Cyberculture, 2017, pp. 25 e ss.

${ }_{192}$ Segundo Ana GARRIGA DOMÍNGUEZ (Nuevos retos para la protección de datos personales en la era del Big Data y de la computación ubicua. Madrid, Dykinson, 2015, pp. 25), em 2013, o Google processava mais de 24 petadados/dia e o Facebook subia 10 milhões de fotos/hora, impondo novos desafios no âmbito dos direitos fundamentais.

${ }^{193}$ Yuval Noah HARARI, Homo Deus: Uma breve história do amanhã. $1^{\text {a }}$. Edição. São Paulo: Companhia das Letras. 2016, pp. 12.

194 João José Nogueira de ALMEIDA, Sobre o controlo dos auxílios de Estado na União Europeia. Conteúdo, sentido e limites da análise económica na avaliação da compatibilidade dos auxílios de Estado com o mercado interno, Dissertação de Doutoramento em Ciências Jurídico-Económicas. Faculdade de Direito da Universidade de Coimbra, Coimbra. 2012, pp. 240.

195 Natalino IRTI, Norma e luoghi, Problemi di geo-diritto. Roma-Bari: Laterza. (2001 pp. 23 e ss).

${ }^{196}$ Ver Miguel REALE, Teoria Tridimensional do Direito, 4ª Ed. São Paulo: Saraiva, 1986. 
Geografia perante uma interdisciplinaridade com o Direito, é chave para a identificação do critério espacial do Direito e do critério coercitivo da Geografia.

Dentro desta tridimensionalidade, o problema que se coloca é como a Geografia e o Direito utilizam a Infraestrutura de Dados Espaciais (IDEs) enquanto instrumento de cadastramento e mapeamento de fatos geográficos e jurídicos (enquanto fenômenos ordenados territorialmente) para alcançar uma mediação de interesses espaciais. Em outras palavras, estudar os critérios espaciais do direito somente faz sentido se for para mediar objetivamente conflitos territoriais. Direito é justiça, Geografia é espaço. ${ }^{197}$ Se por um lado justiça espacial pode ser considerada um pleonasmo, por outro ela demonstra como se decompõe analiticamente o objetivo de se estudar, concomitantemente, Geografia e Direito em prol de uma cidadania especializada, da composição das disputas espaciais.

A importância da mediação de conflitos territoriais tem sido subestimada. Os estudos empíricos não têm reconhecido que a condição da Estatística, ${ }^{198}$ da Geografia e da Cartografia para o alcance desse objetivo é de imprescindibilidade, pois elas tendem a eliminar a sobreposição de títulos imobiliários principalmente em países em desenvolvimento. Estas ciências, quando convergem para um único modelo de política pública, formam uma espécie de "infraestrutura da infraestrutura", pois sem elas nada se edifica, o Estado não se sustenta, suas políticas em saúde, educação, habitação, segurança, transporte, recreação, turismo, serviços sociais pessoais, dentre outras, ficam sem um lugar no espaço. Elas deixam de compor um sistema público para serem iniciativas aleatórias. Em outras palavras, no data, no policies. ${ }^{199}$ O Comitê Geoespacial da ONU conferiu boa medida da amplitude destas possibilidades, quando afirmou que a infraestrutura geográfica terá no século XXI a importância que a energia elétrica teve no século XX, dado que será uma infraestrutura tão essencial e invisível quanto o elétron ${ }^{200}$ e os governos serão mais reguladores e menos produtores de dados geoespaciais.

Tomando o Geodireito como um dado posto, a questão central passa a ser identificar como e qual conjunto de tecnologias disruptivas, promotoras de geoinformação, servirão ao papel de bens de domínio público, passíveis de regulação e de universalização com dados atualizados,

\footnotetext{
197 Para Andreas PHILIPPOPOULOS-MIHALOPOULOS (Spatial Justice. Body, Lawscape, Atmosphere. Abingdon: Routledge, 2015, pp.15), não há justiça sem que ela seja espacializada.

198 George BOYNE, Territorial justice: A review of theory and evidence, Political Geography Quarterly. Volume 10, Issue 3, 1991, pp. 263.

${ }^{199}$ Raffaele MARCHETTI, Global Strategic Engagement: States and Non-State Actors in Global Governance. Lexington Books, 2016, pp 29.

${ }^{200}$ UNITED NATIONS. United Nations Initiative on Global Geospatial Information (UN-GGIM), Future trends in geospatial information management: the five to ten-year vision, First edition, English version, July 2013, pp. 34.
}

Revista Eletrônica: Tempo - Técnica - Território, V.10, N.1 (2019), 01:51 ISSN: 2177-4366 
41 A Geografia, Antes de mais nada, Serve para Mediar a Paz pela Infraestrutura de Dados Espaciais da Geopolítica ao Geodireito

interoperáveis, de fácil acesso e módicos. E nesta busca, a Infraestrutura de Dados Espaciais dos países ocupa papel central.

A IDE tem inúmeras aplicabilidades. Como exemplo, ela tem o poder de transformar o ordenamento territorial ${ }^{201}$ de um país, que tem suas atividades econômicas distribuídas racionalmente em termos geográficos, ${ }^{202} \mathrm{em}$ um grande e estruturado programa computacional, pois não se produzirá ordenamento territorial no século XXI sem Sistema de Informação Geográfica, com importantes repercussões urbanísticas, ambientais e agrárias, principalmente em suas lacunas normativas. ${ }^{203}$

A IDE também tem papel central para a gestão de desastres naturais. A ocorrência de força maior é quase impossível de se mitigar, mas seu impacto pode ser minimizado por uma avaliação inicial relacionada ao mapeamento de vulnerabilidade. $\mathrm{O}$ desenvolvimento da tecnologia de sensoriamento remoto e suas aplicações permitem a utilização de imagens de satélite para observar estas áreas afetadas. ${ }^{204}$ Isso foi aplicável em ao menos três fenômenos recentes: o tsunami de Fukushima, no Japão, ${ }^{205}$ o furacão Katrina, nos Estados Unidos, ${ }^{206}$ e o incêndio florestal em Portugal, de 2017. Neste último caso, Pedrógão Grande, a localidade em que o incêndio iniciou, tinha o menor número de fotos Flickr sobre Portugal, sendo de apenas

\footnotetext{
${ }^{201}$ Para Fernando ALVES CORREIA (Manual de Direito do Urbanismo. Vol. I, $4^{\mathrm{a}}$ ed., Coimbra, Almedina. 2008, pp. 73), o ordenamento territorial nasce de uma preocupação geográfica, quando afirma que o termo se origina no quadro geográfico de França para uma melhor repartição dos homens em função dos recursos naturais e das atividades económicas.

${ }^{202}$ Fernanda Paula OLIVEIRA, Direito do Urbanismo. Do Planeamento à Gestão. 2a . Edição, Aedrl Nedal. 2015, pp. 14.

${ }^{203}$ Para Fernanda Paula OLIVEIRA, Maria José Castanheira NEVES e Dulce LOPES (Regime Jurídico da Urbanização e Edificação Comentado. 4a. Edição, Ed. Almedina, 2016 pp. 70), "[n]a ausência de uma previsão legal de registo predial destes "ônus", impõe-se um reforço dos Sistemas de Informação Geográfica direcionados para os novos pedidos que chegam ao município ou, então, a criação de sistemas de registo públicos em que estas situações de consumpção de edificabilidade fiquem plasmadas. Nestes registos públicos poderiam igualmente figurar as situações de transferências de edificabilidade (previstas no artigo 21. da Lei n. 31/2014, de 30 de maio), que não vão a registo predial, por não se cingirem aos termos limitados em que se encontra consagrado esse registo no artigo 179, n. 3, do RJIGT.".

${ }^{204}$ Abu Bakar SAMBAH, Fusanori MIURA, Spatial data analysis and remote sensing for observing tsunamiinundated areas. International Journal of Remote Sensing. Volume 37, Issue 9: Ocean remote sensing for sustainable resources. United Kingdom, 2016.

${ }^{205}$ Federica RANGHIERI, Mikio ISHIWATARI, Learning from Megadisasters: Lessons from the Great East Japan Earthquake. World Bank Publications. 2014, pp. 236.

${ }^{206}$ GEOLOGICAL SURVEY, U.S., Science and the Storms: The USGS Response to the Hurricanes of 2005. U.S. Geological Survey. Circular 1306, Paperback, 2007, pp. 54.
} 
oito imagens. ${ }^{207}$ É um cenário que dificulta a tomada de decisão em momentos de crise como a ocorrida, pela precariedade de dados sobre a localidade afetada pelo incêndio. ${ }^{208}$

Informação geográfica se presta a atender finalidades públicas das mais diversas, tanto quanto possa conceber nossa imaginação. Pode, como exemplo, mapear pontos de ônibus em Manhattan, ${ }^{209}$ coletar lixo em município no interior do Canadá, ${ }^{210}$ realizar um efetivo controle de fauna, ${ }^{211}$ dentre diversas outras possibilidades. Desde o final do século XX, não se cogita a existência de carros autônomos sem uma estruturada infraestrutura de dados espaciais. ${ }^{212} \mathrm{Em}$ suma, ter uma Cidade Inteligente (Smart City) sem infraestrutura de dados espaciais, enquanto pressuposto das Redes Inteligentes (Smart Grid), é como criar um sistema de distribuição de energia elétrica sem geração que a justifique, é um sistema logístico sem produto ou, em uma linguagem canônica, um corpo sem alma que o anime.

Não construir a Infraestrutura de Dados Espaciais enquanto um bem de domínio público franqueia exclusivamente a iniciativa privada o ordenamento territorial por meio de softwares internacionais de mapeamento, pois elas dominam as ferramentas tecnológicas aptas a enfrentar este paradigma neste início de século. Dissociar a gestão territorial desta visão tecnológica confina as possibilidades das entidades governamentais a questões meramente analógicas, aos simples ritos cartoriais, ao baixo emprego de mapas enquanto elemento de prova de propriedade e a repetição de erros seculares, caso da sobreposição de títulos cartoriais, devastação de florestas, dentre outros. É a criação de uma relação de dependência dos usuários de tecnologias a demandas privadas para o exercício de funções públicas: o Geoescravo.

Por outro lado, em um cenário de Datacracia, há um futuro próspero para os cidadãos de estados que estiverem atentos a estas possibilidades enquanto bem de domínio público, atribuindo caráter de essencialidade. A compreensão de políticas públicas em função da geoinformação impõe uma enorme mudança de paradigma no relacionamento entre público e privado. Se pela norma a Administração Pública deve regular e supervisionar as atuações privadas, por meio de dados e mapas oficiais produzidos e padronizados pela IDE os privados

\footnotetext{
207 Jacinto ESTIMA, Marco PAINHO, User Generated spatial Content sources for Land Use/Land Cover validation purposes: suitability analysis and integration model. Tese de doutoramento em Sistemas de Informação. Instituto Superior de Estatística e Gestão de Informação. Universidade Nova de Lisboa, Lisboa, 2015, pp. 67-68. 208 Para efeitos de comparação, Lisboa é o município com os maiores valores para o número de fotos e de densidade, com respectivamente 140.684 fotos e por volta de 1.656 fotos por $\mathrm{km}^{2}$.

${ }^{209}$ Baruch CUNY, Manhattan Bus Stops, New York NY, Faculty Digital Archive, New York University, Spatial Data Repository, 2016.

${ }^{210}$ Bruce WILSON, Betsy AGAR, Brian BAETZ e Anne WINNING. Practical applications for global positioning system data from solid waste collection vehicle”. Can. J. Civ. Eng. 34: 678-681, NRC Canada. 2007 pp. 679. Refere-se ao município de Hamilton.

${ }^{211}$ JACK H. BERRYMAN INSTITUTE Human-wildlife Conflicts, Volume 3. Snippet view. 2009, pp. 69.

${ }^{212}$ Daniel PAGAC, Eduardo NEBOT e Hugh DURRANT-WHYTE. An evidential approach to map-building for autonomous vehicles". IEEE J. Robotics and Automation, 14(4), 1998, pp. 624.
}

Revista Eletrônica: Tempo - Técnica - Território, V.10, N.1 (2019), 01:51 ISSN: 2177-4366 
exigirão da Administração Pública ferramenta tecnológica que forneça dados e mapas oficiais para o exercício de direitos e garantias.

A IDE incentiva a construção de uma cidadania genuinamente ativa. ${ }^{213}$ Sua edificação é o verdadeiro - talvez até então o único - discrímen entre a alienação privada do Geoescravo e a liberdade individual exercida pela Datacracia, situações que impõem formas distintas de percepção do território no nível nacional, regional e do lugar, criando correlações com finalidades distintas, mas que podem vir a ser complementares, dependendo da governança pública a ser conduzida.

Um dos casos mais paradigmáticos do uso da IDE como política pública e bem de domínio público, talvez o melhor exemplo atual de aplicação dessa solução seja o “One Map Policy" da Indonésia, que serve de paradigma para o desenvolvimento de políticas públicas setoriais. Em que pese todos os exemplos acima, o "maior arquipélago do mundo", com mais de 3.700 ilhas que sofrem tremores praticamente todos os dias, o presidente Joko Widodo lançou, em dezembro de 2018, um Geoportal com dados espaciais que servem de referência para o uso da terra por todas as instituições do governo, bem como pelo público em geral.

Widodo disse que o mapa único servirá para coibir a questão da sobreposição de títulos, criando situação concreta de mediação de conflitos jurídicos com base geográfica. Para tanto houve ordem expressa para que todos os órgãos públicos usem o Geoportal para dirimir conflitos territoriais com base em Infraestrutura de Dados Espaciais. Ele também acredita que a ferramenta terá um forte efeito didático para que os cidadãos comuns passem a entender conceitos de ordenamento do território e usos múltiplos de recursos naturais.

As principais atividades no âmbito do One Map Policy são: (i) a fixação do monopólio natural para o mapa público, que deve ser um e ter caráter de oficialidade; (ii) a compilação de mapas temáticos; (iii) a integração e a correção de mapas temáticos com base no mapa básico; e (iv) a sincronização e resolução da sobreposição de mapas temáticos por meio de uma agência reguladora, a Geospatial Information Agency (BIG). ${ }^{214}$ Com esta política pública, o território se torna mais preciso, obtendo bases reais para um planejamento efetivo, servindo de exemplo para o desenvolvimento da Infraestrutura de Dados Espaciais enquanto elemento central da

\footnotetext{
${ }^{213}$ Alexandra ARAGÃO, Uma Europa inspiradora: Sustentabilidade e justiça territorial através dos sistemas de informação geográfica. Boletim de Ciências Econômicas, Homenagem ao Professor Doutor António José Avelãs Nunes, Volume LVII, Tomo I, Luís Pedro Cunha et al. (Org). Coimbra. 2014, pp. 430.

${ }^{214}$ Os mapas temáticos integrados foram inseridos em um sítio próprio e podem ser acessados em http://portal.inasdi.or.id.
}

Revista Eletrônica: Tempo - Técnica - Território, V.10, N.1 (2019), 01:51 ISSN: 2177-4366 
mediação de conflitos territoriais. Esta talvez seja a senha para que a Geografia, de ciência da guerra, adquira uma função muito mais nobre por meio do fomento da paz.

\section{CONCLUSAO}

Aristóteles, em um apotegma notório, afirmou que a natureza tem horror ao vácuo. Tudo ocupa um lugar no espaço, e estudar este fenômeno em função do Direito tem o potencial de oferecer respostas a todo o critério espacial contido na norma, na jurisprudência e demais fontes, com importantes desmembramentos.

O pulsar da sociedade, manifestada em distintas formas de solidariedade, somente será possível por meio de uma coesão territorial patrocinada pelo Geodireito. Ele arfa na confluência do padrão ordem/desordem do Direito em função da dialética centralização/descentralização da Geografia. É a ciência do onde com força cogente, em prol da mediação de conflitos territoriais. Com isso, uma compreensão interdisciplinar entre Geografia e Direito, com base tridimensional (fato, valor e técnica) se faz necessária para enfrentar os desafios tecnológicos do século XXI.

Em um ambiente de Datacracia, um Estado sem dados públicos confiáveis, acessíveis, interoperáveis e atualizados, por meio de uma infraestrutura de dados espaciais, é um país desconhecido. A linha tênue que separará o exercício de uma cidadania ativa em oposição a um cenário sombrio, como o disposto na célebre obra 1984 ou pelo conceito de Geoescravo, será a garantia e a manutenção das liberdades individuais em um ambiente de tecnologia disruptiva, que alcança caráter de crescente e rápida essencialidade enquanto bem de domínio público.

A história da humanidade ensina que Direito Administrativo, Geografia, Cartografia e Estatística devem caminhar em conjunto na promoção de políticas públicas geográficas. No século XXI, pensar em Geodireito é fundamental, pois cidadãos sem geoinformação pública serão, cada vez mais, alienados às ferramentas privadas com interesses mercadológicos próprios. Cabem aos Estados evitar que se criem novas formas de castas na sociedade, entre aqueles que detêm dados privados e sabem correlacioná-los e aqueles que serão excluídos de relações perante estas tecnologias pela ausência de ação pública. Seria um futuro tão negro quanto imaginar um passado que tivesse intencionalmente dividido a sociedade, no século XX, entre aqueles que teriam acesso à energia elétrica e os que estavam confinados à escuridão. 


\section{Referências bibliográficas}

ADEGOKE, Adewale (2017). "Standards and Interoperability in the Nigerian Land Sector". 2017 World Bank Conference on Land and Poverty, The World Bank - Washington DC, March 20-24.

ALICARNASSO, Dionigi di (27). “Antichità Romane”. Libro IX, domínio público.

ALMEIDA, João José Nogueira de (2012). “Sobre o controlo dos auxílios de Estado na União Europeia. Conteúdo, sentido e limites da análise económica na avaliação da compatibilidade dos auxílios de Estado com o mercado interno”. Dissertação de Doutoramento em Ciências Jurídico-Económicas. Faculdade de Direito da Universidade de Coimbra, Coimbra.

ALVES, José Augusto dos Santos (2006). "O Marquês de Pombal e a mudança de paradigma”, Cultura, Vol. 22, 177-192.

ALVES CORREIA, Fernando (2008). "Manual de Direito do Urbanismo". Vol. I, 4ª ed., Coimbra, Almedina.

ARAGÃO, Alexandra (2014). "Uma Europa inspiradora: Sustentabilidade e justiça territorial através dos sistemas de informação geográfica". Boletim de Ciências Econômicas, Homenagem ao Professor Doutor António José Avelãs Nunes, Volume LVII, Tomo I, Luís Pedro Cunha et al. (Org.), Coimbra, pp. 426-453.

AUGSBERG, Ino (2014). "Informationsverwaltungsrecht. Zur kognitiven Dimension der rechtlichen Steuerung von Verwaltungsentscheidungen", Tübingen.

BELTRAMINO, Juan Carlos (1994). "Jornadas sobre derecho y geografía: rationale de la relación interdisciplinaria derecho-geografía”. Biblioteca de La Facultad de Derecho y Cs. Sociales, 341.2 J 36273. Argentina: Manantial.

BLOMLEY, Nicholas; DELANEY, David; FORD, Richard (2001). "The Legal Geographies Reader”. New Jersey: Blackwell Publishers, 2001.

BLOOR, David (1991). “Knowledge and Social Imagery”. Chicago: The University of Chicago Press.

BOYNE, George (1991). "Territorial justice: A review of theory and evidence". Political Geography Quarterly. Volume 10, Issue 3, pages 263-281. 
CASTRO, María Victoria. "Derecho, espacio y poder. Aproximación a la geografia legal desde el análisis distributivo". Tesis de Doctorado en Derecho en proceso de evaluación, Universidad de Los Andes: Bogotá, 2015.

CHARBONNEAU, Hubert; LÉGARÉ, Jacques (1967). "La population du Canada aux recensements de 1666 et 1667’. Population, 22e année, nº, pp. 1031-1054

CHO, George (2005). "Geographic Information Science: Mastering the Legal Issues”. John Wiley \& Sons, 474p.

CLAIRIN, Rémy. (1981). “Quelques reflections sur la collecte démographique”. Paris, Coopération Statéco 25.

CUMBE, Raúl Afonso; CARNEIRO, Andrea Flávia Tenório (2014). “Um estudo para o aperfeiçoamento da cartografia sistemática de Moçambique com base na experiência brasileira”. V Simpósio Brasileiro de Ciências Geodésicas e Tecnologias da Geoinformação. Recife, 12-14 de novembro.

CUNHA, Mafalda Soares da (1993). <<A questão jurídica na crise dinástica >> In MATTOSO, José. "História de Portugal: No alvorecer da modernidade (1480-1620)". Editorial Estampa, 607p.

CUNY, Baruch (2016). "Manhattan Bus Stops, New York NY.” Faculty Digital Archive, New York University, Spatial Data Repository.

DARWIN, Charles (1859). “On the origin of species by means of natural selection”. London, John Murray, 1st edition.

DAVID, René (1966). “Géographie juridique”. Encyclopédie de la Pléiade, Géographie générale, Paris, Gallimard, p. 1738-1748.

DOBSON, Jerome; FISHER, Peter (2003). “GeoSlavery”. Technology and Society Magazine, IEEE, Volume 22, Issue 1 p. 47-52.

DOS SANTOS, José Nicolau. (1955). “Direito Comparado e Geografia Jurídica”. Revista da Faculdade de Direito. Universidade do Paraná, Curitiba, ano 3, n. 3. (1954). "Fundamentos da Geografia Jurídica". Revista da Faculdade de Direito do Paraná, Paraná, v. 2, p. 174-261.

(1952). “ONU - Estado, Proto-Estado ou Super-Estado?” Curitiba: Ed. Guaíra. (1951). "Geografia humana e teoria geral do Estado". Ciências correlatas. Curitiba: Ed. Guaíra.

ESTIMA, Jacinto; PAINHO, Marco (2015). “User Generated spatial Content sources for Land Use/Land Cover validation purposes: suitability analysis and integration model.” Tese 
de doutoramento em Sistemas de Informação. Instituto Superior de Estatística e Gestão de Informação. Universidade Nova de Lisboa, Lisboa, Portugal.

GARRIGA DOMÍNGUEZ, Ana (2015). "Nuevos retos para la protección de datos personales en la era del Big Data y de la computación ubicua”. Madrid, Dykinson, 266 p. ISBN 978-84-9085-653-6

GASPAR, Joaquim Alves (2004). "Dicionário de ciências cartográficas”. Lisboa ; Porto : Lidel. GEOLOGICAL SURVEY (U.S.) (2007). "Science and the Storms: The USGS Response to the Hurricanes of 2005”. U.S. Geological Survey. Circular 1306, Paperback, 282p. ISBN10: 1411320042

GNEDENKO, Boris Vladimirovich (ГНЕДЕНКО, Б. В., 1950), “Курс теории вероятностей”. Москва: Государственное издательство технико-математической литературы.

GREAT BRITAIN PARLIAMENT (2008). "Counting the Population, Volume 1". House of Commons. Treasury Committee The Stationery Office. ISBN 9780215520593.

HARARI, Yuval Noah (2016). "Homo Deus: Uma breve história do amanhã”. 1ª Edição. São Paulo: Companhia das Letras.

HEIDEGGER, Martin (2002). <<A questão da técnica >>. In: "Ensaios e Conferências". Petrópolis: Vozes.

HOLDER, Jane; HARRISON, Carolyn (2003). "Law and Geography". Oxford University Press, Vol. 5, 2003.

HUMBOLDT, Alexander von (1858). "Kosmos. Entwurf einer physischen Weltbeschreibung". Bd. 4. Stuttgart.

IRTI, Natalino (2001). "Norma e luoghi, Problemi di geo-diritto". Roma-Bari: Laterza.

ISRO - Indian Space Research Organisation (2001). "National Spatial Data Infrastructure: Strategy and Action Plan”. Discussion Document. ISRONNRMS-SP-75-2001, Bangalore.

JACK H. BERRYMAN INSTITUTE (2009). "Human-wildlife Conflicts”, Volume 3. Snippet view.

KERCKHOVE, Derrick de (2017). <<Mobile culture in Singapore>>, In Tellería, Ana Serrano. "Between the Public and Private in Mobile Communication". Series Routledge Studies in New Media and Cyberculture, 2017. 
KITOKO, Dilson; PAINHO, Marco (2015). “A informação geográfica em Angola: subsídios para a elaboração de uma estratégia e plano de ação de apoio à implementação do plano nacional de informação geográfica”. Publicado por Imprensa da Universidade de Coimbra, Coimbra.

KOLBE-BOOYSEN, Olivia (2017). "The Challenges of Using Spatial and Demographic Data for Development in Nigeria”. 2017 World Bank Conference on Land and Poverty, The World Bank - Washington DC, March 20-24.

KONAN, Kouadio (2006) "Réseau Géodésique de Côte d'Ivoire (RGCI)", document de vulgarisation publié par BNETD/CCT, 2ème édition, Abidjan, novembre, 6p.

LACOSTE, Yves (1976) “La géographie, ça sert, d'abord, à faire la guerre”. Paris, Maspero. 187 pages. Petite coll. Maspero n. 165.

LAFFITTE, Pierre (1887). "A general view of Chinese civilization and of the relations of the West with China”. London, Teubnee \& Co., Ludgate Hill.

LANGHANS-RATZEBURG, Manfred (1932). "Geopolitik und Geojurisprudenz". Jena, Frommannsche Buchhandlung - W. Biedermann.

LATOUR, Bruno (1991). “Nous n'avons jamais été modernes, Essai d'anthropologie symétrique”. Paris, La Dé-couverte.

LÍTER, Carmen; HERRERO, Ana; SANCHÍS, Francisca (1996). "La geografía entre los siglos XVI y XVII". Madrid, Ediciones Akal. ISBN 84-460-0593-X

LOSANO, Mario G. (2012). "Diritto e geografia: lo spazio del diritto e il mondo della geografia”. Legal Roots: The International Journal of Roman Law, Legal History and Comparative Law, n. 1, p. 05-21

MACKINDER, H. J. (1904). "The Geographical Pivot of History”. The Geographical Journal, v. 23, n. 4 , pp. 421-437.

MALTHUS, Thomas (1826); "Essay on the Principle of population"; London, John Murray, 6th edition.

MARCHETTI, Raffaele (2016). "Global Strategic Engagement: States and Non-State Actors in Global Governance”. Lexington Books, 210p.

MATOS, João (2008). "Fundamentos de Informação Geográfica”. LIDEL - Edições Técnicas, $1^{\mathrm{a}}$ Edição, Lisboa, 405 p.

MATTOSO, José (2014). “D. Afonso Henriques”. $2^{\mathrm{a}}$ Ed. Lisboa: Temas E Debates. ISBN 978972-759-911-0 
MCLAUGHLIN, John (1991). “Towards National Spatial Data Infrastructure”. Proceedings of the 1991 Canadian Conference on GIS, Ottawa, Canada, 1-5. Ottawa: Canadian Institute of Geomatics.

MITCHAM, Carl (1990). “QQué es la filosofía de la tecnología?” Barcelona: Anthropos Editorial del Hombre.

MONTAÑEZ GÓMEZ, Gustavo (1999). "Elementos de historiografía de la Geografía colombiana”. Revista de Estudios Sociales, Bogotá, No 3 .

NICOLET, Claude (1988). "Contrôle de l'espace humain : les recensements". L'inventaire du monde: géographie et politique aux origines de l'Empire romain. Paris: Fayard.

NILES, Susan A. (2007). "Considering Quipus: Andean Knotted String Records in Analytical Context". Taylor and Francis. ISSN 0093-8157.

NOWELL, Charles (1982). "The Rose-colored map. Portugal attempt to build an African empire from the Atlantic to the Indian Ocean”. Junta de Investigações Cinetíficas do Ultramar, Lisboa.

OLIVEIRA, Fernanda Paula (2015). "Direito do Urbanismo. Do Planeamento à Gestão". 2a . Edição, Aedrl Nedal.

; NEVES, Maria José Castanheira; LOPES, Dulce (2016). "Regime Jurídico da Urbanização e Edificação Comentado". 4ª Edição, Ed. Almedina.

ORTEGA Y GASSET, José (1998). "Meditación de la técnica y otros ensayos sobre ciência y filosofia". Madrid: Alianza. (1998). “Tierras de Castilla”. El espectador. Madrid: Alianza, p. 177-192.

ORWELL, George (2005). “1984”. 29 Ed. São Paulo: Companhia Ed. Nacional.

PAGAC, Daniel; NEBOT, Eduardo; DURRANT-WHITE, Hugh (1998). “An evidential approach to map-building for autonomous vehicles". IEEE J. Robotics and Automation, 14(4):623-629.

PALMER, Alan (1976). "Kings and Queens of England”. Great Britain: Octopus Books Limited. ISBN 0706405420.

PHILIPPOPOULOS-MIHALOPOULOS, Andreas (2015). "Spatial Justice. Body, Lawscape, Atmosphere". Abingdon: Routledge.

PLATT, Rutherford H. (1976). "Land Use Control: Interface of Law and Geography". Washington: Association of American Geographers. 
RANDLE, Patricio H. (1994). "Derecho, geografía urbana y urbanismo”. Bib. Fac. Derecho y Cs. Sociales, 341.2 J 36273, Argentina: Manantial.

RANGHIERI, Federica; ISHIWATARI Mikio (2014). "Learning from Megadisasters: Lessons from the Great East Japan Earthquake". World Bank Publications, 388p.

RATZEL, Friedrich (1901). "Der Lebensraum : eine biogeographische Studie". Tübingen : H. Laupp.

REALE, Miguel (1986). “Teoria Tridimensional do Direito”. 4a. Ed. São Paulo: Saraiva.

REILLY, Bernard (1992). “A evolução da sociedade Ibérica (1031-1072)”. In:

Cristãos e Muçulmanos: A luta pela Península Ibérica. Editora Teorema.

REY BALMACEDA, Raúl C., (1994). "La región geográfica frente al derecho”. Biblioteca de La Facultad de Derecho y Cs. Sociales, 341.2 J 36273, Argentina: Manantial.

ROBINSON, M. (2008). “A History of Spatial Data Coordination”. Federal Geographic Data Committee Reports and Presentations. USA.

SAMBAH, Abu Bakar; MIURA, Fusanori. "Spatial data analysis and remote sensing for observing tsunami-inundated areas". Encontrado em <http://dx.doi.org/10.1080/01431161.2015.1136450>, julho de 2017.

SANTOS, Boaventura de Sousa (1988). "Uma cartografia simbólica das representações sociais: Prolegómenos a uma concepção pós-moderna do direito”. Revista Crítica de Ciências Sociais, n. 24. Coimbra.

SANTOS, José Gomes dos. (2014). "Jangada de SIG na administração pública portuguesa", Trabalho apresentado em I Jornadas Lusófonas de Ciências e Tecnologias de Informação Geográfica, In Actas das I Jornadas Lusófonas de Ciências e Tecnologias de Informação Geográfica, Coimbra.

SANTOS, Milton (2009). “Território e Sociedade”. $2^{\mathrm{a}}$ ed. $4^{\mathrm{a}}$ reimpressão. São Paulo: Editora Fundação Perseu Abramo.

SIMAV, Mehmet (2012). "National Report of Turkey". National Mapping Agency, General Command of Mapping from Turkey. EUREF 2012 Symposium, Poland. 2012.

SINGH, P.K. (2005). "Governance Issues in GIS Infrastructure in India”. International Journal of Rural Management, 1(2): 223-244.

SORRE, Max (1950). "Les fondements de la Géographie Humaine”. Paris : Librarie Armand Colin.

TAVARES DA SILVA, Suzana (2014). "Direitos fundamentais na arena global”, $2^{\text {a }}$ Edição. Imprensa da Universidade de Coimbra : Coimbra. ISBN Digital 978-989-26-0877-8 
51 A Geografia, Antes de mais nada, Serve para Mediar a Paz pela Infraestrutura de Dados Espaciais da Geopolítica ao Geodireito

(2010). “Um novo Direito Administrativo?”. Imprensa da Universidade de Coimbra : Coimbra.

UGEDA, Luiz (2017). "Direito Administrativo Geográfico - Fundamentos na Geografia e na Cartografia oficial do Brasil”. Brasília: Instituto Geodireito Editora, 424p.

UNITED NATIONS. United Nations Initiative on Global Geospatial Information (UN-GGIM) (2013). "Future trends in geospatial information management: the five to ten year vision", First edition, English version, July 2013.

VIDAL DE LA BLACHE, Paul (1913). “Des caractères distinctifs de la Géographie”. Annales De Géographie, 22 (124): 289·299, Paris.

VINOKUROV, Evgeny (2007). “A Theory of Enclaves”. Lexington Books.

WHITTLESEY (1935), Derwent. "The Impress of Effective Central Authority upon the Landscape". Annals of the Association of American Geographers. v. 25, n. 2, p. 8597.

WILSON, Bruce G.; AGAR, Betsy J.; BAETZ, Brian W.; WINNING, Anne (2007). "Practical applications for global positioning system data from solid waste collection vehicles". Can. J. Civ. Eng. 34: 678-681, 2007 NRC Canada. 